\title{
Bilingual Education as a Status Conflict
}

\author{
Rachel F. Moran $\dagger$
}

America has evolved for the better. She will pretty much meet you on your terms. In fact, I think that she has finally come to the conclusion that the Blacks, Mexicans, Indians, etc. are here to stay. And the only way to perceive them is to aceept them and their existence as valid. Acceptance, that's really the key word. America is accepting all the people, as one people, the way it was meant to be. Today, at least, you can afford to be yourself.

-Maria, a Hispanic social worker ${ }^{1}$

We have room for but one language here and that is the Enghish language, for we intend to see that the crucible turns our people out as American, of American nationality, and not as dwellers in a polyglot boarding house.

-Theodore Roosevelt, as reprinted in a recent U.S. Enghish brochure ${ }^{2}$

These voices bear witness to the conflict engendered by ethnic, linguistic, and cultural diversity. Especially since the 1960's, this conflict has frequently been addressed through the legal process, rather than through more informal means. Hispanics, for example, have repeatedly expressed concerns about their language and culture in promoting programs for non-Enghsh-proficient (NEP) and limited-English-proficient (LEP) children. They have often pressed for bilingual-bicultural education progranis, which not only promote proficiency in Enghish but also foster hteracy in the native language and respect for the child's cultural heritage. ${ }^{3}$ Hispanics have also endorsed transitional bilingual education (TBE) programs that utilize subject-inatter instruction in a student's

$\dagger$ Acting Professor of Law, Boalt Hall School of Law, University of California, Berkeley. A.B. 1978, Stanford University; J.D. 1981, Yale Law School. I would like to acknowledge the helpful comments of Richard Buxbaum, Sheldon Messinger, Robert Post, Martin Shapiro, Jan Vetter, and Franklin Zimring. I owe a special debt to Steve Sugarman for support and guidance that went well beyond the call of duty. I would also like to express my gratitude to ny research assistant, Martha Jiminez, who checrfully, methodically, and indefatigably pursued the history of federal bilingual education law with nie.

1. Monrcal, Maria, Social Worker, Comments, in Sighs AND Songs of AzTLAN 100, 101-02 (F. Albi \& J. Nieto eds. 1975).

2. U.S. Enghish, In Defense of Our Common Language . . . (infornational brochure, n.d.).

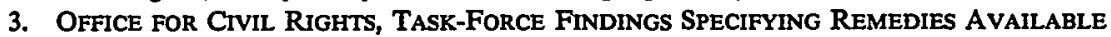
for Eliminating Past Educational Practices Ruled Unlawful Under Lau v. Nichols, at 
native language until the child is sufficiently proficient in English to participate in a regular classroom. To facilitate acquisition of English, the child typically learns to read in both the native language and English. ${ }^{4}$

Critics of bilingual-bicultural education and TBE programs have argued that schools can best proinote proficiency in Enghish by minimizmg rehance on the student's native language in the instructional process. They have pushed for Enghish as a Second Language (ESL) and structured immersion programs. In ESL programs, hinguistic minority children spend inost of the day in regular classes but receive additional instruction in English for part of the day. ${ }^{5}$ Structured iminersion programs use English to teach subject matter, although the teacher speaks both the native language and Enghish. Children may ask questions about a subject in the native language, but the teacher generally responds only in English. The curriculuin is structured so that extensive knowledge of English is not assumed as subjects are taught, and the program may provide thirty to sixty minutes of native-language instruction per day. ${ }^{6}$ In addition to advocating these alternative instructional approaches, some opponents of bilingual-bicultural education and TBE programs have supported Enghish-only requirenents in the schools to ensure the continuing preeminence of English. ${ }^{7}$

Typically, these disputes have been analyzed as yet another example of special interest groups' bargaining over the allocation of scarce resources. The crudest version of this analysis asserts that Hispanics support bilingual-bicultural education and TBE programs because they provide them with jobs as teachers and teachers' aides. ${ }^{8}$ For example, in an extreinely influential article published in Harper's magazine in 1979, Toin Bethel stated that "[t]he bilingual education program is more or less the Hispanic equivalent of affirmative action." This view fails to explain why Hispamics lave concluded that eleinentary and secondary schools provide a particularly fertile source of employment, especially in light of overall shrinking student enrollments. ${ }^{10}$ Perhaps Hispanics are

\$ IX, pt. 1 (1975), reprinted in Bilingual Education 213, 221 (K. Baker \& A. de Kanter eds. 1983).

4. Id. at $\S \mathrm{IX}$, pt. 5, reprinted in Bilingual Education, supra note 3, at 221; Baker \& de Kanter, Federal Policy and the Effectiveness of Bilingual Education, in Bilingual Education, supra note 3, at 33, 35.

5. Baker \& de Kanter, supra note 4, at 34.

6. Id.

7. See infra notes 55-64 and accompanying text.

8. N. Epstein, LANGUAGE, ETHNicity AND THE Schools 38 (1978) (remarks of A. Bruce Gaarder, former chief of the United States Office of Education's Modern Foreign Language Section); Bethell, Against Bilingual Education: Why Johnny Can't Speak English, HARPER's, Feb. 1979, at 30.

9. Bethell, supra note 8, at 30; see also San Miguel, Confict and Controversy in the Evolution of Bilingual Education in the United States-An Interpretation, 65 Soc. ScI. Q. 505, 512-13 (1984).

10. Levin, An Analysis of the Federal Attempt to Regulate Bilingual Education: Protecting Civil Rights or Controlling Curriculum?, 12 J.L. \& EDuc. 29, 52 (1983). In California, there was a steady 
unconcerned about this general decline because the population of NEP and LEP pupils is growing. ${ }^{11}$ Still, it seems unlikely that these activists wholly failed to anticipate that Enghish-speaking teachers would lodge objections based on their semority if they were displaced by a bilingual education "jobs program" for Hispanics. ${ }^{12}$

Moreover, bilingual education statutes have typically included waiver provisions that enable English-speaking teachers to instruct NEP and LEP students while acquiring bilingual teaching skills. ${ }^{13}$ These provisions have been necessary because of the lack of qualified bilingual teachers. ${ }^{14}$ The prevalence of waiver provisions raises two troubling problems for tliose who treat bilingual education as inerely a "jobs program" for Hispanics. First, it seems surprising that Hispanics would concentrate on generating employment opportunities in a field in which a pool of qualified Hispanics is not readily available. ${ }^{15}$ Second, once waiver

declime in enrollments during the 1970's but a gradual mcrease in the early 1980's. This increase is expected to continue as children of the "baby boomlet" enter the public schools. ASSEMBLY OfFICE OF RESEARCH, CALIFORNIA 2000, at 15 (June 1986).

11. The Hispanic Population: Hearings Before the Subcomm. on Census and Population of the House Comm. on Post Office and Civil Service, 98th Cong., 1st Sess. 91 (1983) (statement of Dr. Gloria Zamora, President, National Association for Bilingual Education); Bilingual Education: Hearing on H.R. 11 and H.R. 5231 Before the Subcomm. on Elementary, Secondary, and Vocational Educ, of the House Comm. on Educ. \& Labor, 98th Cong., 2d Sess. 124-25 (1984) [hereinafter 1984 House Hearings] (prepared statement of Dr. M. Joan Parent, President, National School Boards Association). In California, a recent report indicated that by the 1990's, at least $15 \%$ of the students would arrive at school without any knowledge of English. ASSEMBLY OFFICE OF RESEARCH, supra note 10 , at 15 (basing estimate on paper presented to California Board of Education by Norman G. Gold in 1985).

12. In fact, such objections did quite predictably materialize. See, e.g., Morris v. Brentwood Union Free School Dist., 52 A.D.2d 584, 383 N.Y.S.2d 542, leave to appeal denied, 40 N.Y.2d 802 (1976) (granting tenured English-speaking teachers' petitions for reinstatement when they were dismissed while more jumior bilingual teachers were retained); 60 Op. Cal. Att'y Gen. 80 (1977) (upholding district's right to retain junior nontenured teachers with bilingual competency while terminating seuior tenured teachers without such competency where the district had adopted a bilingual education program pursuant to the California Education Code); $59 \mathrm{Op}$. Cal. Att'y Gen. 73 (1976) (same).

13. See R. Irizarry, Bilingual Education 24-25 (1978) ("Where teachers are not available with the established qualifications, provisions in the legislation frequently allow for exemptions."); Assembly OfFice OF RESEARCH, BILINGUAL EduCation 18 (1986) (approximately $40 \%$ of the teachers in bilingual education programs in California have waivers; $60 \%$ of them are "non-Hispanic white.")

14. 1984 House Hearings, supra note 11, at 56-57 (prepared statement of Gumecindo Salas, Chairperson, Michigan State Board of Education); id. at 72 (prepared statement of Dr. Gloria Zamora, President, National Association for Bilingual Education); id. at 84 (prepared statement of Nguyen Ngoc Bich, President-Elect, National Association for Vietnamese American Education); id. at 113 (prepared statement of Guillermo Lopez, State Director of Bilmgual Education Office, California Department of Education).

15. Schoolteachers must be college graduates. Hispamics complete 10.5 years of schooling compared with 12.5 years for the non-Hispanic white population. The high school dropout rate for Hispanics is $18 \%$, and in large urban areas, the rate is often found to be as high as $50 \%-70 \%$. Of Hispanic high school graduates, fewer than $30 \%$ go on to college, a drop from $35.5 \%$ during 1975 to 1982. Of these, fewer than $50 \%$ actually graduate from college. Sotomayor, Demographic 
provisions became a fairly uniform feature of bilingual education statutes, their potential as a source of jobs for Hispanics was considerably diminished. Yet advocates did not reduce their vigorous commitment to bilingual education by redirecting their attention to other programs for increasing Hispanic einployinent. ${ }^{16}$ Thus, although bilingual education programs have undoubtedly generated some jobs for Hispanics, this simple form of interest-group bargaining analysis hardly provides a comprehensive explanation of Hispanics' efforts to promote bilingual education reforms.

A more sophisticated interest-group bargaining analysis attributes the government's endorseinent of bilingual education programs to Hispanies' growing political clout. According to this view, as Hispanics have grown in numbers, ${ }^{17}$ they have been able to exercise more influence over the political process in proinoting their self-interest. Not only have legislators in general becoine inore responsive to Hispanic views, but more Hispanics have also been elected or appoimted to political office. In addition, Hispanic lobbying groups have become mcreasingly experienced and effective as they have ganied greater access to the governmental decisioumaking process. ${ }^{18}$

While this view provides some helpful insights into the bihingual education controversy, it too is not a completely satisfying analysis. To

Characteristics of U.S. Hispanic Populations, in HISPANICS IN AN AGING SocIETY 15, 17-18 (TorresGil ed. 1986).

16. Although Hispanics have always pursued other avenues of reform, such as employment discrimination claims, they continue to participate heavily in legislative hearings and litigation related to bilingual education. See, eg., Avila, Equal Educational Opportunities for Language Minority Children, 55 U. CoLo. L. Rev. 559, 559, 569 (1984) (describing Mexican American Legal Defense and Educational Fund's investment of over one million dollars to identify and promotc educational programs providing the greatest opporturities for Hispanic students).

17. Sotonayor, supra note 15 (projecting that by the year 2000, the Hispanic population will be the fastest growing major ethnic group in the Umited States based on Bureau of the Census figures).

18. For various analyses of bilingual education policy that reflect interest-group bargaining considerations, see A. LeIBowitz, THE BILINGUAL EDUCATION ACT 9-10 (1980); E. MoshER, A. Hastings \& J. Wagoner, JR., Pursuing Equal Educational Opportunity 13 (1979); M. Rebell \& A. Block, Educational Policy Making and the Courts 193-94 (1982); San Miguel, supra note 9, at 506. The analysis here is representative of these approaches without exhaustively describing their subtle variations.

Although the number of Hispanics elected to local, state, and national offices increased from 3,128 to 3,202 between 1980 and 1985 , Hispanics still hold fewer than $1 \%$ of the nation's elected offices. Sotomayor, supra note 15, at 18. Moreover, although the number of Hispanic women who were eligible to vote and went to the polls increased between 1978 and 1982, overall registration and voting participation for presidential elections during this period was lower than in 1972. In the last presidential election, $36 \%$ of Hispanics 18 years old and over indicated that they had registered to vote, but only $30 \%$ voted. Id. The consistently low voter turn-out among Hispanics presents some scrious difficulties for an interest-group bargaining model that relies on Hispanics' growing political clout. It is possible, however, that legislators based their actions on a belief that Hispanics would mobilize more effectively in the future. 
begin with, this approach does not explain why Hispanics consider bilingual-bicultural education and TBE progranis to be of such central importance in advancing their interests. Hispanics have remained strong adherents of these progranis, although einpirical studies have produced mixed evidence on their effectiveness in proinoting academic achievement. ${ }^{19}$ Even taking into account the inethodological weaknesses of some of these studies, ${ }^{20}$ an interest-group bargaining analysis does little to clarify Hispanics' unswerving support for these progranis and their reluctance to substitute ESL and structured immersion prograins.

Similarly, this analysis does not explani why Englislı speakers with no direct stake in the dispute have dedicated themselves to imposing Enghish-only requirements that would potentially eliminate bilingualbicultural education and TBE progranis. Obviously, Enghish-speaking teachers whose jobs are threatened by such programs could be expected to intervene to protect their economic interests. More baffling, however, is the lieavy involveınent of Englisl1-speaking individuals who liave little or no direct contact with the schools or with bilingual-bicultural education and TBE prograins. ${ }^{21}$ Agam, because interest-group bargaining analysis fails to address the underlying process of preference formulation, it can slied hittle liglit on this question.

To address these deficiencies in interest-group bargaining approaclies, this Essay will utilize status conflict analysis to describe low participants in the bilingual education controversy liave used language as a proxy for the status of their culture, custoins, and values. It will argue that the participants' preoccupation with the respect and deference accorded to their way of life has strongly influenced the debate over bilingual education. Part I will first briefly recount the history of bilingual education policyinaking at the federal level, examine two case studies of bilingual education litigation, and describe the bilingual education and Englisli-only inoveinents. After a review in Part II of earlier work on status conflicts, Part III will apply this theoretical franiework to the poli-

19. E.g., AMERICAN INSTITUTES FOR RESEARCh (AIR), EVALUATION OF THE IMPACT OF ESEA TITLE VII SPanish/English Bilingual Education Program (1977-78); Baker \& de Kanter, supra note 4, at 50-51; Baker \& de Kanter, Assessing the Legal Profession's Contribution to the Education of Bilingual Students, 1 LA RAzA L.J. 295, 309-15 (1986).

20. See, e.g., Intercultural Development Research Association, The AIR Evaluation of the IMPact of ESEA TITLE VII SPanish/ENGlish BILINGUal Education Programs (Eric Ed No. 151-435, 1977); Cardenas, Response I, in N. Epstein, supra note 8, at 74 75. Recently, a General Accounting Office draft report concluded that the Department of Education had misinterpreted bilingual education research, thereby downplaying the benefits of native-language instruction for NEP and LEP children. May, U.S. Faulted on Bilingual Education, L.A. Times, Nov. 8, 1986, § I, at 20, col. 1 .

21. For example, one of the leaders in the push for English-only reforms is an opthalmologist from Petoskey, Michigan. Only about 200 of Petoskey's 6,100 residents are nonwhite, and almost all of them speak English. Trombley, Prop. 63 Roots Traced to Small Michigan City, L.A. Times, Oct. $20,1986, \S \mathrm{I}$, at 3 , col. 1 . See infra notes $58,177-78$ and accompanying text. 
cymaking and litigation processes in the bilingual education field. It will also evaluate low status concerns have influenced the evolution of the bilingual education and English-only movements. Part IV will close with soine tentative suggestions about the future of bilingual education policymaking and litigation, as well as the prospective development of the bilingual education and Englisli-only moveinents.

\section{I}

\section{AN OVERVIEW OF THE Bilingual EdUCATION CONTROVERSY}

The debate over bilingual education has raged since the 1960 's before a variety of governmental decisionmakers. ${ }^{22}$ This controversy will first be examined by reviewing the process througl which relevant federal statutes were enacted and applied. Because Hispanics have frequently brought suit to enforce bilingual education provisions, this Part will next describe two empirical studies of such cases. It will then contrast the reform strategies employed by the bilingual education and English-only movements.

\section{A. The Policymaking Process}

In 1968, amid considerable fanfare, Congress enacted the Bilingual Education Act, the first piece of federal legislation devoted exclusively to the special educational needs of NEP and LEP children. ${ }^{23}$ Witnesses expressed high lopes for the bill. They argued that bilingual education programs would promote academic achievement, thereby enabling Hispanics to participate more fully in the social, economic, and political life of the nation. ${ }^{24}$ Several witnesses indicated that bilingual education programs were significant for Hispanics because they represented the scliools' acceptance of the Spanish language and the best hope for mutual

22. There have been earlier disputes over language issues in the United States. The Founders deeided not to establish an official language in tlie Constitution, in part because they feared that such a provision would infringe on the rehgious freedom of churches conducting services in languages other than English. Heath, English in Our Language Heritage, in LANGUAGE IN THE U.S.A. 6, 6-7, 12 (C. Ferguson \& S. Heath eds. 1981). During the late 1800's and early 1900's, controversy arose over German instruction in public and private schools. Id. at 14-17; see generally H. KLOSS, THE AMERICAN BILINGUAL TRADITION 45, 46-47, 52-53, 60-61, 67-74 (1977) (describing early efforts to suppress use of German in the United States).

23. Bilingual Education Act of 1968, Pub. L. No. 90-247, 81 Stat. 816 (codified as amended at 20 U.S.C. $\S \S 3221-3262$ (1982)).

24. See, e.g., Bilingual Education Programs: Hearings on H.R. 9840 and H.R. 10224 Before the General Subcomm. on Educ. of the House Comm. on Educ. \& Labor, 90th Cong., 1st Sess. 144-47 (1967) (statement of Rep. Edward Roybal); id. at 245-47 (statement of Herunan Badillo, President, Borough of the Bronx, New York City); see also C. HaRrington, BiLINGual Education iN the UNITED STATES 2-3 (1980); A. LeIBowitz, supra note 18, at 20-23; E. MosheR, A. HASTINGS \& J. WAGONER, JR., supra note 18 , at 13 . 
understanding and respect..$^{25}$

For all this stirring rhetoric, the Bilingual Education Act was actually a quite modest grant-in-aid program designed to meet the needs of NEP and LEP children by promoting research and experimentation. ${ }^{26}$ The Act never clearly defined bilingual education, im part because of an unresolved ambiguity about the programs' proper objectives. Some supporters saw the legislation simply as a way to maximize proficiency in English, while others viewed it as a means of furthering proficiency in both the native language and English and of instilling respect for the child's cultural heritage. ${ }^{27}$ From 1968 to 1974, appropriations under the Act were significantly lower than autliorized expenditures, but no popular outcry ensued. ${ }^{28}$

Between 1968 and 1974, bilingual education proponents struggled to create and enforce an entitlement to special educational services for NEP and LEP children. Title VI, an omnibus civil rights bill enacted im 1964, provided that "[n]o person in the United States shall, on the basis of race, color, or national origin, be excluded fron participation $\mathrm{m}$, be denied the benefits of, or be subjected to discrimination under any program or activity receiving federal financial assistance."29 Congress left to the Office of Civil Rights (OCR) the task of elaborating on this broad, but rather ill-defined, mandate by promulgating and enforcing regulations. ${ }^{30}$ Altliough Congress had not exphicitly considered the problems of NEP and LEP children ni enacting title VI, OCR issued a 1970 memorandum concluding that the provision barred discrimination agamst national origui-minority group children on the basis of language. ${ }^{31}$ How-

25. Bilingual Education: Hearings on S. 428 Before the Special Subcomm. on Bilingual Education of the Senate Comm. on Labor and Public Welfare, 90th Cong., 1st Sess. 327 (1967) [hereinafter 1967 Senate Hcarings] (remarks of Joe Bernal, Texas State Senate); id. at 382 (remarks of Tony Calderon, Representative of the Federation for the Advancement of Mexican Americans).

26. The Act "provide[d] financial assistance to local educational agencies to develop and carry out new and imaginative elementary and secondary school programs designed to meet the special educational needs [of NEP and LEP children]." 20 U.S.C. $\$ 880 \mathrm{~b}$ (as amended by Pub. L. No. 93 380, $\S 105$ (a)(1), 88 Stat. 503 (1975); omitted in codification by Pub. L. No. 95-561, § 701, 92 Stat. 2268 (1978)). According to the Senate Committee Report, the Act did not prescribe a specific type of program because of the need for extensive research. S. REP. No. 726, 90th Cong., 1st Sess. 50 (1967), reprinted in 1967 U.S. CoDE CONG. \& ADM1N. NEwS 2730, 2781.

The Act authorized $\$ 15$ million in appropriations for the fiscal year ending June 30, 1968; $\$ 30$ million, for the fiscal year ending June 30,1969; $\$ 40$ unillion for the fiscal year ending June 30, 1970; $\$ 80$ million for the fiscal year ending June 30, 1971; $\$ 100$ million for the fiscal year ending June 30 , 1972; and $\$ 135$ inillion for the fiscal year ending June 30, 1973. 20 U.S.C. $\$ 880 b-1$ (a).

27. D. Ravitch, The Troubled Crusade 273 (1983).

28. Executive Office of the President, Office of Management and Budget, The Budgets OF THE UNITED STATES GOVERNMENT FISCAL YEARS 1969-1975 (1968-1973).

29. 42 U.S.C. $\$ 2000$ d. 1980).

30. Rabkin, Office for Civil Rights, in The Politics of Regulation 307-13 (J. Wilson ed.

31. Identification of Discrimination and Denial of Services on the Basis of National Origin, 35 
ever, this memorandum went largely unenforced. ${ }^{32}$

In 1974, the Supreme Court adopted OCR's interpretation of title VI in its widely publicized decision in Lau v. Nichols. ${ }^{33}$ In Lau, a class action brought by Chinese NEP and LEP children in the San Francisco schools, the plaintiffs estabhshed that approximately 1,800 Chinesespeaking children were receiving no special assistance whatsoever. The Court concluded that under title VI as interpreted by OCR, the district was obligated to take some steps to rectify the language barrier when Enghish-only imstruction had the effect of excluding NEP and LEP children from meaningful participation in the educational prograin. ${ }^{34}$ However, it left the task of designing a reinedy to local school officials. ${ }^{35}$

Lau triggered a number of responses. It had significant effects on the allocation of resources to bilingual education. Following discussions on whether school districts could marshall the resources necessary to comply with Lau, Congress began to authorize and appropriate more funds under the Bilingual Education Act. ${ }^{36}$ State legislatures also

Fed. Reg. 11595 (1970) (requiring school districts to take affirmative steps to rectify a language barrier where it exclnded national origin-minority group children from effective participation in the educational program); see also Margulies, Bilingual Education, Rentedial Language Instruction, Title VI, and Proof of Discriminatory Purpose: A Suggested Approach, 17 ColUM. J.L. \& Soc. PROBS. 99, 115 (1981) (history of administrative interpretations of title VI's protection of NEP and LEP children).

32. San Miguel, supra note 9, at 507. For a general description of some of the enforcement problems that have plagued OCR, see Rabkin, supra note 30, at 304-53.

33. 414 U.S. 563 (1974).

34. Id. at 566-69. The Court asserted:

Imposition of a requirement that, before a child can effectively participate in the educational program, he must already have acquired those basic skills is to make a mockery of public education. We know that those who do not understand English arc certain to find their classroom experiences wholly incomprehensible and in no way meaningful.

Id. at 566. The Court went on to conclude that "the Chinese-speaking minority receives fewer benefits than the English-speaking majority from [the] school system whicl denies them a meaningful opportumity to participate in the educational program." Id. at 568.

35. Id. at 564-65. The Court stated that although no specific remedy was requested, "[t]eaching English to the stndents of Chinese ancestry who do not speak the language is one choice. Giving instructions to this group in Chinese is another. There may be others." Id. at 565 .

36. For some representative statements on the problems of complying with Lau, see Bilingual Education Act: Hearings on H.R. 1085, H.R. 2490, and H.R. 11464 Before the General Subcomm. on Educ. of the House Comm. on Educ. \& Labor, 93d Cong., 2d Sess. 7 (1974) (remarks of Rep. Lloyd Meeds); id. at 7-9 (remarks of Stanley Pottinger, Assistant Attorney General, Civil Rights Division, U.S. Department of Justice); id. at 20-32 (remarks of Martin Gerry, Acting Director, Office for Civil Riglits, Department of Health, Education, and Welfare).

Amendments to the Bihingual Education Act in 1974 anthorized $\$ 135$ million for the fiscal year ending June 30, 1974; $\$ 135$ million for the fiseal year ending June 30,1975 ; $\$ 140$ million for the fiseal year ending June 30, 1976; $\$ 150$ million for the fiscal year ending June 30, 1977; and $\$ 160$ million for the year ending June 30, 1978. Bilingual Education Act of 1974, § 702(b)(1), Pub. L. No. 93-380, $\$ 105(\mathrm{a})(1), 88$ Stat. 484, 504 (1974). In addition, the amendments authorized $\$ 7.75$ million for technieal assistance in the fiscal year ending Jnne 30, 1976; $\$ 8.75$ million in the fiscal year ending June 30, 1977; and $\$ 9.75$ million in the fiscal year ending June 30, 1978. Id. $\$ 702(b)(2)$. More importantly, actual appropriations in 1974 and later years more closely approximated authorized 
enacted their own bilingual education acts and appropriated monies under these provisions. ${ }^{37}$

OCR stepped up its enforcement efforts by promulgating guidelines for districts to use in coinplying with Lau and applying these guidelines in negotiating consent agreeinents. ${ }^{38}$ These guidelines went well beyond the minimal entitleinent recognized in Lau by endorsing bilingual-bicultural education and TBE programs and deeming ESL programs mappropriate for elententary school students. ${ }^{39}$

Congress also expressed its approval of Lau by passing the Equal Educational Opportunity Act (EEOA), which included a provision that exphicitly adopted the decision's approach. The provision stated, "No State shall deny equal educational opportunity to an individual on account of his or her race, color, sex, or national origin, by ... (f) the failure by an educational agency to take appropriate action to overcome language barriers that impede equal participation by its students in its instructional programs." 40 Because the measure was enacted as an annendinent from the floor, there was httle legislative history to guide its interpretation. $^{41}$

After 1974, Hispamics turned to the federal district courts to enforce NEP and LEP students' entitleinent to special educational services. ${ }^{42}$ While these lawsuits were being brought with varying degrees of success

levels of expenditure. Executive Office of the President, Office of MaNAGEMENT aNd Budget, The Budgets of the United States Government FisCal Years 1976-1980 (19741978).

37. E. Mosher, A. HASTINGS \& J. WAGONER, JR., supra note 18, at 16 . See generally R. IRIZARRY, supra note 13 , at 45-128 (collecting data on state bilingual education legislation). In general, state bilingual education acts declare the state's commitinent to meeting the needs of NEP and LEP students, provide for the identification and assessment of these students, describe the kinds of programs that will meet these needs, set forth requirements for staffing and parental involvement, and authorize state funding. See Kobrick, A Model Act Providing for Transitional Bilingual Education Programs in Public Schools, 9 HARV. J. on LEgis. 260, 274-300 (1972).

38. OfFICE FOR CIVIL Rights, supra note 3, reprinted in BILINGUAl EduCATION, supra note 3, at 213-21; see also E. MOSHER, A. HASTINGS \& J. WAGONER, JR., supra note 18, at 16 (federal enforcement efforts imcreased after $L a u$ ).

39. OfFICE For Civil Rights, supra note 3, at III, reprinted in BILINGUal EdUCATION, supra note 3, at 215-18. See generally Margulies, supra note 31, at 116 (describing how HEW drafted and disseminated the Lau guidelines).

40. 20 U.S.C. \& $1703(f)$ (1982).

41. United States v. Texas, S06 F. Supp. 405, 431-32 (E.D. Tex. 1981), rev'd, 680 F.2d 356 (5th Cir. 1982); Haft, Assuring Equal Educational Opportunity for Language-Minority Students: Bilingual Education and the Equal Educational Opportunity Act of 1974, 18 CoLUM. J.L. \& Soc. ProBs. 209, 233 (1983).

42. See, e.g., Guadalupe Org. v. Teinpe Elementary School Dist., 587 F.2d 1022 (9th Cir. 1978); Cintron v. Brentwood Union Free School Dist., 455 F. Supp. 57 (E.D.N.Y. 1978); Rios v. Read, 73 F.R.D. 589 (E.D.N.Y. 1977); Otero v. Mesa County Valley School Dist., 408 F. Supp. 162 (D. Colo. 1975), vacated, 568 F.2d 1312 (10th Cir. 1977); Aspira of New York v. Board of Educ., 394 F. Supp. 1161 (S.D.N.Y. 1975); Keyes v. School Dist. No. 1, 380 F. Supp. 673 (D. Colo. 1974), modified, 521 F.2d 465 (10th Cir. 1975), cert. denied, 423 U.S. 1066 (1976), on remand, 576 F. Supp. 1503 (1983). 
around the country, the federal government commissioned a systematic inquiry mto the effectiveness of programs funded under the Bilingual Education Act. The results of this study, known as the AIR evaluation, were released in 1977-78. They indicated that the prograins were not effective im promoting Enghish proficiency and resulted in classrooin segregation of Hisparic children. ${ }^{43}$ Despite protests that the study was methodologically unsound, these results had a sobering effect on Congress as it reconsidered its commitment to the Bilingual Education Act. ${ }^{44}$ After 1978, Congress became imcreasingly receptive to efforts to broaden the range of programs that would be funded under the Act. In particular, it expressly acknowledged that structured mmiersion and ESL programs might be viable alternatives to bilingual-bicultural education and TBE programs. ${ }^{45}$ Concomitantly, funding under the Act steadily declined. ${ }^{46}$

In 1978, the Supreme Court also began to retreat from the Lau decision by suggesting that it would no longer find a title VI violation when a program merely had the effect of excludimg a disproportionate number of racial or ethnic minorities. In Regents of the University of California $v$. Bakke, ${ }^{47}$ a majority of the Court appeared ready to treat title VI and the equal protection clause as coextensive, thereby requiring plaintiffs to prove discriminatory intent as well as an adverse effect under both provisions. Although the Court did not expressly overrule Lau, the Bakke decision cast serious doubt on its holding. ${ }^{48}$

Shortly thereafter, the demise of the Lau guidelines further eroded

43. III AMERICAN INSTITUTES FOR RESEARCH (AIR), supra note 19, at IV-2 to IV-4.

44. For critiques of the study, see INTERCULTURAL DEVELOPMENT RESEARCH ASSOCIATION, supra note 20; Cardenas, supra note 20, at 74-75. For evidence of the effect that the study had on legislators, see Bilingual Education: Hearings on H.R. 15 Before the Subcomm. on Elementary, Secondary, and Vocational Educ. of the House Comm. on Educ. \& Labor, 9Sth Cong., 1st Sess. 352 (1977) [hereinafter 1977 House Hearings] (remarks of Christopher Cross, Minority Senior Education Consultant) ("[Critics] have indicated ... . that we should not use the AIR report to base our judgments on changes. If not, what should we use?").

45. See, e.g., 1984 House Hearings, supra note 11, at 99-100 (remarks of Reps. Steve Bartlett and Ron Packard); id. at 131-32 (prepared statement of Rep. Norman Shumway); id. at 132-33 (prepared statement of Rep. William Whitehurst); The Bilingual Education Improvement Act of 1983: Hearings on H.R. 2682 Before the Subcomm. on Elementary, Secondary, and Vocational Educ. of the House Comm. on Educ. \& Labor, 98th Cong., 1st Sess. 22-23 (1983) [hereinafter 1983 House Hearings] (prepared statement of Terrel H. Bell, Secretary of Education); id. at 31 (remarks of Rep. Ron Packard). In 1984, the Act was amended to reserve a specified percentage of funds for ESL, structured immersion, and similar programs. The total amounts that could be allocated to thesc programs were carefully limited. 20 U.S.C. § 3222(b)(3)-(4) (Supp. III 1985).

46. Orum \& Yzaguirre, Secretary Bennett's Bilingual Education Initiative: Historical Perspectives and Implications, 1 LA RAZA L.J. 225, 235 (1986). The Undersecretary of Education has suggested that if the cap on funds that can be allocated to ESL and structured immersion programs were lifted, the Department of Education would increase funding for programs for NEP and LEP children. Id. at 239.

47. 438 U.S. 265 (1978).

48. Id. at 304-05; Margulies, supra note 31, at 130; see also Guardians Ass'n v. Civil Servicc 
NEP and LEP children's entitlement to special educational services under title VI. In 1978, an Alaska school district challenged the validity of the Lau guidelines in federal district court, alleging that they were tantamount to rules and had not been published for notice and comment as required by the Administrative Procedure Act. Pursuant to a consent agreement, the federal government agreed to publish the guidelines. ${ }^{49}$

Rather than publish the Lau guidelines, the newly formed Department of Education published a Notice of Proposed Rulemaking (NPRM) in 1980. The regional hearings on the NPRM were a political free-for-all, rife with stinging accusations. Opponents, including influential teachers' umions, bitterly attacked the regulations, and newspaper articles likening the Department of Education's approach to that in Quebec heightened the tension. ${ }^{50}$ The controversy became so unmanageable that the NPRM was never finalized..$^{51}$ Later, the $L a u$ guidelines were quietly withdrawn, and the controlling administrative regulation under title VI is now OCR's 1970 memorandum. ${ }^{52}$

Because of these developments, most bilingual education hitigation today is decided under the EEOA, which looks only at whether a program has the effect of excluding NEP and LEP students from the educational program and does not require proof of discriminatory intent. ${ }^{53}$ Although the EEOA allows plamtiffs to establish a violation more easily, its remedial consequences are different from those under the $L a u$ guidelines. In contrast to the guidelines, which strongly endorsed bilingualbicultural education and TBE programs, the EEOA's "appropriate action" requirement is arguably broad enough to encompass ESL and structured immersion programs as well. ${ }^{54}$

In 1981, Senator S.I. Hayakawa began introducing proposals to ainend the Constitution to declare Enghish the official language of the United States. ${ }^{55}$ Hayakawa argued that among other things, an Enghish language amendment would counter the divisive effects of bilingualbicultural education and TBE programs. ${ }^{56} \mathrm{He}$ feared that failure to pro-

Comm'n, 463 U.S. 582, 589-93 (1983) (opinion of White, J.) (analyzing whether Bakke overruled Lau by making title VI coexteusive with the equal protection clause).

49. Northwest Arctic School Dist. v. Califano, No. A-77-216 (D. Alaska Sept. 29, 1978).

50. Levin, supra note 10, at 51-52.

51. Id. at 39-40, 50, 56-57.

52. Baker \& de Kanter, supra note 19 , at 307.

53. Haft, supra note 41, at 211-15 (1983); Marguhes, supra note 31, at 108-09.

54. See Castaneda v. Pickard, 648 F.2d 989, 1008-09 (5th Cir. 1981) (“Congress' use of the less specific term 'appropriate action,' rather than 'bilingual education,' indicates that Congress intended to leave state and local educational authorities a substantial amount of latitude in choosing the programs and techniques they would use to mect their obligatious under the EEOA."). But $c f$. Haft, supra note 41, at 263 (arguing that Congress in enacting the EEOA intended to advance already existing legislative and administrative policies favoring the use of bilingual-bicultural inethods).

55. S.J. Res. 72, 97th Cong., 1st Sess., 127 CoNG. REC. $7444-45$ (1981).

56. The English Language Amendment: Hearing on S.J. Res. 167 Before the Subcomm. on the 
mote a common language would produce instability and unrest as it had in other countries witl balkanized language groups. ${ }^{57}$ Hayakawa also founded U.S. English, a national organization devoted to preserving English as the official language of the United States. Its meinbership is composed primarily of individuals who lave also worked to curb immigration, first-generation immigrants who learned English as a second language, and Englisl1-speaking schoolteachers. ${ }^{58}$ When Hayakawa's repeated efforts to amend the Constitution failed, U.S. Englisl attempted to have Enghisl declared an official language at the state and local level througl popular referenda and legislative action. ${ }^{59}$

These efforts liave stirred deep enotional responses. For exainple, when the California cliapter of U.S. Englislı used the referendum process to inake English the state's official language, opponents contended tliat the nieasure conveyed a symbolic message that culturally and linguistically different groups were unwanted. ${ }^{60}$ They alleged that the campaign was a thinly veiled forn 1 of racism and derived from anti-immigrant sentiment. $^{61}$ The proposal's supporters argued that it was a common sense way to ensure that California's population remained pohitically cohesive. $^{62}$ After spirited debate, tlie proposal passed by an overwlielning majority in November $1986 .{ }^{63}$ Hayakawa's followers succeeded in mak-

Constitution of the Senate Comm. on the Judiciary, 98th Cong., 2d Sess. 54-56 (1984) (statement of Sen. Hayakawa). Hayakawa also expressed concern about the widespread use of bilingual ballots and election materials. Id. at 53.

57. See generally Note, The Proposed English Language Amendment: Shield or Sword?, 3 YALE L. \& PoL'Y REV. 519 (1985) (describing recent efforts to make English the official language, analogizing these atteinpts to the Americanizatiou moveinent of the early twentieth century, and urging that such an amendment would be inappropriate despite the possible validity of some of its supporters' concerns).

58. A. Galvan, R. Macias, R. Magallan \& L. Orum, Are English language AMENDMENTS IN THE NATIONAL INTERest? 2-3 (1986); Cahan, English Spoken Here, 13 STUDENT LAW. 6 (Apr. 1985); Trombley, supra note 21.

59. Cahan, supra note 58, at 6; Nakao, Battle of Words Heats Up over 'English Only,' San Francisco Examiner, Sept. 21, 1986, at A1, col. 1.

60. L.A. Times, Oct. 3, 1986, § II, at 4, col. 1; L.A. Times, Aug. 21, 1986, § I, at 23, col. 3.

61. Trombley, English Ballot: Opinions Transcend Language, L.A. Times, Oct. 12, 1986, § I, at 1, col. 2; del Olmo, Se Habla Ingles: Prop. 63, a Cruel Joke, Could Cost Us Dearly, L.A. Times, Aug. 28, 1986, § II, at 5, col. 1; Shaw, Minority Groups Protest 'English Only' Movement, San Francisco Examiner, Aug. 21, 1986, at A2, col. 1. In fact, according to a 1986 November general election survey conducted by Mervin Field, $46 \%$ of those who opposed the English language amendment considered it racist and discriminatory against new immigrants. Among Hispanics, $72 \%$ of those who rejected the measure expressed this view. The California Poll: 1986 November General Election Survey 196, 200 (directed by Mervin Field) (on file with author) [hereinafter California Poll].

62. Troinbley, supra note 61; Nakao, supra note 59.

63. According to Field's 1986 Novenber general election survey, $68 \%$ of those who voted on the proposal favored it, while $32 \%$ opposed it. While $72 \%$ of the white voters and $67 \%$ of the black voters endorsed the measure, $41 \%$ of the Hispanic voters and $56 \%$ of the Asian voters did so. California Poll, supra note 61 , at 186,188 . Of those who cast ballots, $14 \%$ did not vote on the English language amendment. Ten percent of the white voters and $20 \%$ of the black voters did not 
ing English the official language in California just as they have in at least seven other states and numerous cities and counties. ${ }^{64}$

\section{B. The Litigation Process}

The foregoing analysis illuminates the general tenor and complexity of the bilingual education controversy, but this account would be incoinplete without a closer examination of the lawsuits that Hispanics have brought to enforce federally created entitlements. Rather than enumerate the outcomes in various cases, this Section will explore the underlying dynamics of the hitigation process by examining empirical studies of two bilingual education cases. Because of the paucity of empirical research in this area, it is not possible to say whether these studies are representative of most bilingual education hitigation. ${ }^{65}$ Still, their detailed inquiries provide some useful insights into the bilingual education debate.

The first case, Otero v. Mesa County Valley School District No. $5 l^{66}$ was brought in 1974 in a Colorado federal district court by a coalition of attorneys from the Mexican American Legal Defense and Education Fund (MALDEF), the Chicano Education Project (CEP), and Colorado Rural Legal Assistance (CRLA) ${ }^{67}$ Brought on behalf of a class of Mexican-American parents and their children residing in Grand Junction, Colorado, the suit alleged that the district's educational program and hiring practices discriminated against Chicanos. To remedy the problem, the planitiffs requested that the district implement a far-ranging bilingual-bicultural education prograin and institute affirmative action hiring programs for Chicano persolmel. ${ }^{68}$

Several years before the lawsuit was filed, there had been a marked increase in local Chicano pohtical activism. The group primarily responsible for the increased pohtical activity, La Voz de la Raza, spearheaded the lawsuit, and the traditionally nonpoliticized Chicano community associated the case with militancy. The school board thought that La Voz was run by outside "agitators" who wanted to use the litigation as a

register an opinion on the measure. Twelve percent of the Hispanic voters and $9 \%$ of the Asian voters did not do so. Id. at 188 . For further discussion of these results, see supra note 61 and infra note 148.

64. See Note, supra note 57, at 519; Harper's Index, HARPER's, Apr. 1987, at 15; Trombley, Assemblyman Vows to Carry the Ball for English-Only Action, L.A. Tin1es, Nov. 6, 1986, § I, at 3, col. 5.

65. In an effort to increase the available data on bilingual education litigation, I am currently undertaking a case study of Keyes v. School Dist. No. 1, 576 F. Supp. 1503 (D. Colo. 1983).

66. 408 F. Supp. 162 (D. Colo. 1975), remanded on other grounds, 568 F.2d 1312 (10th Cir. 1977), on remand, 470 F. Supp. 326 (1979), aff'd, 628 F.2d 1271 (1980). The case study was done by Michael A. Rebell, a visiting lecturer in law at the Yale Law School, and Arthur A. Block, a lecturer in law at Columbia Law Sclool. M. Rebell \& A. Block, EQuality AND Education (1985).

67. M. REBELL \& A. BLock, supra note 18 , at 147.

68. Id. 
national test case, rather than advance the interests of local Chicanos. Consequently, the board was reluctant to negotiate as a ineans of avoiding a lawsuit, beheving that $\mathrm{La} \mathrm{Voz}$ would ouly be satisfied if the board coinpletely abdicated its responsibility to design a curriculuin responsive to the entire community's needs. ${ }^{69}$

Because Lau had only recently been decided, the hitigants had no well-developed precedents to guide in its interpretation. Understandably, the plaintiffs and the school district in Otero presented markedly different views about Lau's holding. The plaintiffs contended that Lau supported their position that Chicano schoolchildren were discriminated against by a curriculuin that did not account for their linguistic and cultural needs. To remedy such discrimination and ensure that Chicanos reaped equal benefits froin the educational process, they claimed that the district had to adopt a bilingnal-bicultural education progran1. ${ }^{70}$

In contrast, the district interpreted $L a u$ as prohibiting the exclusion of NEP and LEP students from the curriculum based on language. To reinedy such exclusion, the district argued that it was simply obligated to furnish special instruction in Enghish until children were sufficiently proficient to participate in the regular curriculum. According to the district, it had no obligation to ensure that NEP and LEP students actually performed as well as other children after their return to English-only classrooms. $^{71}$

The case was bitterly contested. The discovery process was highly acrimonious, confused, and excessively litigious. Even the usual professional courtesies annong lawyers failed to temper the parties' distrust and hostility. These problenis were exacerbated by the uncertainty surrounding a relatively novel case and the trial judge's desultory efforts to address coinplex discovery issues and facilitate coinpromise. ${ }^{72}$

The case also engendered deep eniotional responses in the community. Although no violence actually occurred in connection with the trial, two Chicanos who planned to testify on the school district's behalf claimed that they had received anonynious death threats. The courtroon was also cleared several times because of boinb threats following accusations that the judge was biased against the plaintiffs. ${ }^{73}$

On a nore positive note, the case served an important educational function. The local newspaper covered the proceedings in considerable detail, even publishing school-by-school dropout statistics. Based on this publicity, one Chicano businessman decided to testify for the plaintiffs

69. Id. at $148-50$.

70. Id. at 152-53.

71. Id. at 151-52.

72. Id. at 153-55.

73. Id. at 282 n.15. 
because their ideas were gaining wider acceptance in the Chicano community. ${ }^{74}$ At the end of the trial, the local newspaper observed that regardless of its outcome, the case had demonstrated the importance of responding to individual student needs, rather than "cramming [all children] into a common Anglo mold."75

The trial court eventually rejected the plaintiffs' claim that Chicano students were entitled to a coinprehensive bilingual-bicultural education program. A civil rights conservative, the judge had been unsympathetic to this argument froin the outset. ${ }^{76}$ Moreover, the plaintiffs were unable to produce convincing evidence that their suggested reinedy was a workable response to the special needs of Chicano children in Grand Junction. The court was never persuaded that the plaintiffs' prograin was essential enough to override the school district's discretion in structuring the curriculum. ${ }^{77}$

In Zambrano v. Oakland Unified School District, ${ }^{78}$ the plaintiffs, a class of Cainbodian, Filipino, Hispanic, and Asian linguistic minority children, alleged that the Oakland school systein in California had failed to implement an adequate bilingual education program as required by federal and state law. The suit asked for injunctive rehef to ensure coinphance and the appointment of an independent auditor to nonitor the district's progress. ${ }^{79}$ The case was filed by Public Advocates, a San Francisco public interest firm, and the plaintiffs received additional assistance fronı attorneys at MALDEF and the Legal Aid Society of Alaineda County. ${ }^{80}$

Filed in 1984, Zambrano differs significantly froin Otero because in the intervening ten years, an administrative and judicial framework had developed to address NEP and LEP students' deınands for special educational services. California had also enacted a coinprehensive bilingual education act, while the Colorado legislature had not addressed such concerns at the time of the Otero decision. ${ }^{81}$ Moreover, the

74. Id. at 150 .

75. Id. (footnote omitted).

76. Id. at $155,167,290 \mathrm{n} .85$.

77. Id. at 172-74. The case generated a plethora of social science evidence regarding the linguistic abihities of Chicano schoolchildren in the district, their educational achievement, and the potential benefits of bilingual-bicultural education. The district enjoyed several advantages in presenting evidence on these questions. It had easier access to the relevant data, its principal expert was thoroughly familiar with the conditions in the district, and it was strongly committed to using social science evidence to refute the plaintiff' expert testimony. Id. at 155-68, 171.

78. No. 584503-9 (Alameda Sup. Ct. May 1, 1985). The ease study was done by Brenda Reyes and Marsha Siegel in conjunction with a seminar on children's rights and test-case litigation at Boalt Hall School of Law.

79. B. Reyes \& M. Siegel, Zambrano v. Oakland Unified School District 1, 60 (1985) (unpublished manuscript) (on file with author).

80. Id. at 47-55.

81. Id. at $10-12$. The Colorado legislature did enact a bilingual education act shortly after the 
demographics of the classroom had changed, and Hispanics were more likely to be jomed by Asian language groups in seeking special assistance for NEP and LEP children. ${ }^{82}$ What remanied unchanged, however, was the animosity that such lawsuits provoked.

During the eight years before Zambrano was brought, four administrative complaints were filed with OCR, and at least two were filed with the California State Department of Education. These complaints consistently resulted in findings of noncoinphance, and the district was repeatedly ordered to prepare plans and submit progress reports. The district did so, but it failed to implement adequately plans that on paper appeared fully operational. ${ }^{83}$

Critical in catalyzing the lawsuit was the creation of a bilingual district advisory committee (BDAC) in Oakland pursuant to California's bilingual education act. Although the district had ignored the BDAC for several years, two activist parents were elected chair and vice-chair and ambitiously sought to develop and implement a bilingual master plan ${ }^{84}$ With help from two curriculum specialists in the district's Office of Bilingual Education, the BDAC prepared a plan for submission at a public hearing before the school board. Noting the BDAC's "advisory" character, the district rejected the plan and presented one of its own. The district's plan, which read the relevant statutes and regulations as narrowly as possible, expressed a strong preference for ESL imstruction and utilized bilingual instructional aides and volunteers, rather than certified bilingual teachers. ${ }^{85}$

Public hearings on the plans attracted as many as 200 to 300 parents and generated media coverage sympathetic to the BDAC's position. In light of this strong interest, the school board was unwilling to approve the district's plan, which many viewed as an illegitimate substitute for the BDAC's proposal. The district superintendent therefore appointed a committee of parents and school personnel to draft yet another plan. The committee's proposal favored native-language instruction as a bridge to learning English and required the district actively to recruit certified

Otero decision. M. REBELl \& A. Block, supra note 18, at 175. While the Colorado act originally endorsed bilingual-bicultural education for kindergarten through third grade, it was amended in 1977 to provide for TBE programs. Id. at 184. More recently, Colorado repealed its bilingual education law, substituting an ESL requirement. Levin, supra note 10, at 57 n.72.

82. According to the Assembly Office of Research, most NEP and LEP children in California schools speak Spanish, but many speak Asian languages, and the latter constitute the fastest growing segment of the linguistic minority population. ASSEMBLY OFFICE OF RESEARCH, supra note 13, at 1.

83. B. Reyes \& M. Siegel, supra note 79 , at $28-37,46$.

84. Id. at 36-40. Most BDAC members were linguistic minority parents, but some were education professionals. Id. at $36-38$.

85. Id. at $40-41$. 
bilingual education teachers. ${ }^{86}$

At a ineeting attended by 300 supporters of the new plan and a nuunber of reporters, the school board approved the committee's plan after heated debate. ${ }^{87}$ The district responded by disinantling its Office of Bilingual Education and reassigning its personnel to positions in which they would be less able to do "politicking" for bilingual education. Thus, the district had a bilingual inaster plan but no central staff to innpleinent it. Althougl1 the superintendent eventually estabhished a new Office of Bilingual Education in response to public pressure, Zambrano was filed less than a year after the district instituted its purge. ${ }^{88}$

In keeping with events leading up to the case, Zambrano generated considerable hostility and distrust among the parties. Although soine district officials treated the suit as a predictable response to the district's history of noncomphance, others were outraged and thouglit the litigation lad undermined their efforts to reorganize the Office of Bilingual Education and implement the new inaster plan. The district's fornal response reflected the view that the plaintiff's' request for an injunction was unnecessary and highly intrusive, although its counsel faced the unenviable task of explaining away eiglit years of admimistrative violations. ${ }^{89}$

The relationship between the attorneys in the case grew increasingly acrimonious. Shortly after the first court hearing, the district's counsel questioned whether a document drafted by plaintiff's' counsel accurately set fortli an oral order in the case. Disputes arose about whether the district had provided the plaintiffs witl adequate notice of inotions and hearings and had served them with copies of orders it obtained. ${ }^{90}$ These problems were aggravated when the court vacated an injunction requiring the district to conduct prompt language assessnients. The district insisted that the plaintiffs post open-ended personal surety bonds as well as a corporate bond to provide for potential damages should the injunctive rehef prove unwarranted. Not surprisingly, the plaintiffs were unable to ineet this demand because of tlieir limited incomes. ${ }^{91}$

Eventually, the district filed a countersuit against the plaintiffs and their attorney for $\$ 250,000$ in general dainages and $\$ 4$ million in punitive dainages, alleging that Zambrano was the product of a conspiracy to

86. Id. at $41-44$.

87. Id. at 42 .

88. Id. at $44-46$.

89. Id. at $65-66,73$.

90. Id. at 83 .

91. Id. at 79-80, 83. The plaintiffs lost their appeals to reinstate the injunction. When they subsequently petitioned the trial court for a new injunction, the district did not demand personal surety bonds. The court granted the injunctive relief. Id. at 81-82. 
"harass, impede, embarrass and obstruct" district operations. ${ }^{92}$ The countersuit claimed that the plaintiffs and their attorney had instigated the suit to "generat[e] negative publicity based on facts known to [them] to be false; pursu[e] destructive, senseless and uunecessary preliminary injunctive rehef while totally refusing to take recourse to their plain and fully adequate administrative reinedy; and unreasonably withhold[] cooperation necessary to coinplete the process of staff appointinents and organizational restructuring."93 Ultimately, a superior court judge dismissed the countersuit and imposed sanctions on the district for bringing a frivolous claim in bad faith..$^{94}$

The district's counsel later deemed the countersuit "a gross political error."95 When a popular outcry followed the district's action, it found itself in a peculiarly untenable position because it had filed the countersuit without first consulting the school board. ${ }^{96}$ The brouhaha that attended the countersuit's filing may well have pushed the district to the settleinent table. Ironically, by this point, the plaintiffs were reluctant to negotiate because they wanted the conpplete victory that a trial could provide. Eventually, however, they were persuaded that negotiations might prove fruitful. ${ }^{97}$

Although a nediator had to be appointed to oversee the settleinent negotiations because of continuing mistrust ainong the parties, an agreement was ultimately hammered out. This successful resolution was in part attributable to ongoing political pressure placed on the school board by community supporters of bilingual education. ${ }^{98}$ The plan required that all NEP and LEP elementary schoolchildren have daily access to sonie form of bilingual instruction. It also expressed a "preference" for a bilingual classroon where thirty or more NEP and LEP secondary students attended a school. In addition, the plan ordered the district to take steps to hire all needed bilingual education teachers and instructional aides. ${ }^{99}$ While the plan has been impleniented under the supervision of a court-appointed nonitor, an expert auditor, and the judge, soine nained plaintiffs have renained active in bilingual education affairs, prinnarily through the BDAC. ${ }^{100}$

While these two cases are in niany ways quite different, they share sone important characteristics. In Otero, the parties confronted a rela-
92. Id. at 84 .
93. Id. at 85 .
94. Id. at 89.
95. Id. at 85 .
96. Id. at $85-88$.
97. Id. at 104-06.
98. Id. at 101-03.
99. Id. at 116-17.
100. Id. at 119, 124-36. 
tively novel entitlement to special assistance for NEP and LEP students; the uncertainty surrounding the interpretation of this claim might have provoked the confusion and ill-will that permeated the proceedings. By the time Zambrano was filed, however, there had been longstanding efforts to define this entitlement more precisely. Nevertheless, the parties voiced fundamental disagreements about the scope of the district's obligation to NEP and LEP children. Moreover, the proceedings were characterized by the same type of deep-seated animosity observed in Otero. Although lawsuits are by definition adversarial, this caimot completely explam the parties' highly contentious behavior, for even the traditional courtesies among lawyers broke down during each case.

\section{The Bilingual Education and English-Only Movements}

The bilingual education movement first pursued reforms at the federal level and then used its successes to press more effectively for changes at the state and local level. It has sought to achieve its objectives through a mix of legislative, administrative, and judicial action. While Congress initially provided a useful forum for publicizing the educational problems of NEP and LEP children, it was ultiniately necessary to turn to a nonelective and less visible decisionmaker, OCR, to establish an entitlement to special educational services for NEP and LEP students. These less publicized efforts culminated in a highly visible Supreme Court decision in Lau. This decision im turn provided bilingual education advocates with additional leverage in seeking further legislative and administrative reforms.

To attain their objectives, bilingual education supporters rehed on omnibus civil rights bills, such as title VI and the EEOA, as well as more narrowly focused legislation, such as the Bilingual Education Act. These omnibus bills did not concentrate on the probleins of NEP and LEP children. Title VI was enacted primarily in response to continuing racial discrimination agamst blacks; it was passed shortly after a brutal assault on civil rights inarchers in Birmingham, Alabama and the 1963 March on Washington. ${ }^{101}$ The EEOA was enacted mainly out of concern about the widespread use of busing as a remedy for past segregation in the schools. Special educational services for NEP and LEP children were siniply an example of the kind of "quality" educational programs that might be substituted for unpopular busing remedies. ${ }^{102}$

To benefit from these omnibus civil rights bills, Hispamics had to ally themselves with other civil rights groups and engage in multipleissue pohtics. ${ }^{103}$ That is, they diversified their political portfolio by

101. Rabkin, supra note 30 , at 309 .

102. Haft, supra note 41 , at 233-34.

103. C. HARRINGTON, supra note 24 , at 2 ; A. LelBowitz, supra note 18 , at 9 . One can also 
expressing support for a broader array of civil rights reforms. Moreover, to bring theinselves within the coverage of these omnibus bills, bilingual education advocates had to argue that language barriers were a proxy for racial and ethnic discrimination. Because this approach sensitized activists to different forms of discrimination and various potential remedies, it naturally limited their ability to engage in single-issue pohitics.

Despite pressures to rely on coalitions, compromises, and multipleissue politics, advocates continued to press for special attention to the needs of NEP and LEP children. They supported the Bilingual Education Act, pursued administrative and judicial recognition of an entitleinent to special services for lingnistic minority students, and urged enactment of state bilingual education acts. Perhaps in part to distinguish themselves from black civil rights groups, Hispanics pressed decisionmakers to accord particular importance to language issues. ${ }^{104}$

In contrast, the Enghish-only movement has been unsuccessful in seeking reforms at the federal level. It has therefore atteinpted to change state and local government practices. Rather than pursue a mix of legislative, administrative, and judicial action, Enghish-only adherents have relied exclusively on popular political processes, including referenda and legislative enactments. By achieving success at the state and local level, English-only supporters hope to create momentum for their national reform agenda. ${ }^{105}$

The Enghish-only movement has remained cominitted to single-issue pohtics, focusing exclusively on language issues without embracing a more generalized reform agenda. ${ }^{106}$ Its proposals continue to treat lan-

analyze bilingual education advocates as "free riders" who benefited disproportionately from the black civil rights movement's investment of resources. Cf. M. OLSON, THE LOOIC OF ColleCTIVE Action 9-16 (1965) (analysis of "free rider" effects where individuals will benefit from activity of groups acting im the collective interest, whether or not the imdividual gives any support to the group). Certainly, in light of the black civil rights movement's successes at the federal level and potential roadblocks at the state and local level, Hispanics advocating bilingual education could havc reasonably concluded that their resources would be optimally deployed at the federal level. See U.S. COMM'N ON CIVIL RIGHTS, A BETTER ChANCE TO LEARN 15-19 (1975) (describing educational neglect of hinguistic minority children prior to federal intervention in the 1960's); U.S. COMM'N ON CIVIL RJGHTS, THE EXCLUDED STUDENT 14-20 (1972) (describing local schools' use of no-Spanish rules and pumitive enforcement techniques). See generally A. OBERSCHALL, SOCIAL CONFLICT AND SOCIAL MOVEMENTS (1973) (theoretical analysis of how social movement groups maximize the use of their scarce resources).

104. See infra note 142.

105. Trombley, supra note 21. The English-only movement is certainly aware that its reforms can command broad support in some regions, in light of the long history of state and local legislation restricting the use of languages other than English. See generally, Leibowitz, English Literacy: Legal Sanction for Discrimination, 45 NoTRE DAME L. REv. 7, 41-42, $51-67$ (1969) (noting numerous state laws establishing English as the exclusive language of instruction in the school system). By first pursuing state and local victories through popular political processes, the Enghish-only movement is arguably optimizing the use of its scarce organizational resources.

106. See, eg., J. Barzun, Language \& Life (undated essay published by U.S. English) (stressing 
guage as uniquely significant and make no effort to link it to other characteristics, such as race, ethnicity, or socioeconomic status.

\section{II}

\section{A Theoretical Framework for ANALyzing the BILINGUAL EDUCATION CONTROVERSY}

Participants in the debate over bilingual education have often responded in deeply emotional ways that seem to transcend immediate concerns with the allocation of scarce resources. Some have openly acknowledged that more than pedagogy is at stake because government support of bilingual education signals acceptance of and respect for the Hispanic community. ${ }^{107}$ A study of bilingual education that overlooks this symbohic component is argnably incomplete. Yet, legal scholars have not scrutinized this impact closely, presumably because such inquiries seem less systematic and scientific than interest-group bargaining analyses. ${ }^{108}$ To address this omission, the Essay will draw on Joseph Gusfield's well-known efforts to develop a framework for understanding status conflicts in the context of the Temperance movement.

Gusfield asserts that status conflicts occur when groups clash in the political arena over the approval, respect, admiration, or deference that they are able to command by virtue of their way of life, including their culture, customs, and values. ${ }^{109}$ When status groups compete with each other to change or defend their prestige allocation, they do so through symbolic actions. The significant ineanings derive not so much from the intrinsic properties of the action but from what it has coine to represent for the participants. The action is ritualistic and cerenionial because the goal is reached in the behavior itself, rather than in any desired state that

need to speak standard English); Tanton, Bilingual Education: Is It Threatening to Divide the United States Along Language Lines?, 33 VITAL Issues (1984) (arguing that linguistic diversity engenders conflict, while a common language promotes socially beneficial cooperation). Although some of the English-only movement's leaders are personally interested in curbing immigration, this has not yet become an organizational objective. Trombley, supra note 21.

107. See supra notes $24-25$ and $60-61$ and accompanying text.

108. For an important exception, see Karst, Paths to Belonging: The Constitution and Cultural Identity, 64 N.C.L. REv. 303, 314-15 (1986), which touches upon the syinbolic components of cultural politics by relying in part on Gusfield's status conflict analysis. See also K. LuKER, ABORtion AND THE POLITICS OF MOTHERHOOD 7-8, 193, 242-43 (1984) (applying status conflict analysis to the abortion controversy).

109. J. Gusfield, Symbolic CRuSAde 17-19 (1963); see also Gusfield, Moral Passage: The Symbolic Process in Public Designations of Deviance, 15 SOC. ProBs. 175, 176-78 (1967). Gusfield's work draws upon Max Weber's earlier distinctions among three factors influencing the distribution of power: class, status group, and party. "Classes" are economic groups composed of persons with roughly the same life chances as determined by market forces. "Status groups" are somewhat amorphous commumities composed of individuals whose life chances are similarly influenced by social estimations of honor or prestige. "Parties" are oriented to exercising power by influencing communal actions, whatever their content. H. GERTH \& C. Mills, From MAX WEBER: Essays IN SOcIOLOGY 180-95 (1946). 
it brings about. ${ }^{110}$ Conflict resolution in syınbolic terins is not necessarily irrational; in fact, it can be a highly useful institutionalized response in the face of social conflicts and tensions manifested in a disarray of the status order as well as other areas of action. ${ }^{111}$

When concerns about status are translated into political disputes, issues are frequently framed in moral terns that seem antithetical to bargaining in a pluralistic process. ${ }^{12}$ The association of an issue with its supporters' way of life can increase the tendency of political issues to turn into matters of "face," freezing the adherents to a given program and diminishing the possibility of compromise or graceful defeat. Because the dispute involves opposition over ways of hife, each side feels compelled to degrade the other's cultural content. ${ }^{113}$ Where status elements are implicated, they often impart an erratic, highly emotional, and disturbing character to the dispute. ${ }^{114}$ Moreover, because status conflicts are highly symbolic, support and opposition frequently come from diverse coalitions that attach broad-ranging connotations to the issues. Status conflicts consequently emerge in diffuse, unfocused forms. ${ }^{115}$

Gusfield carefully distmginshes his treatment of status conflicts froin Murray Edelman's analysis of symbolic politics. ${ }^{116}$ Edelman focuses on how legislative, administrative, and judicial decisionmakers resort to symbohic-expressive cues to appease those who im fact have lost out in the contest for tangible benefits. ${ }^{117}$ Because of symbolic reassurances that their interests are being protected, groups that do not obtain desired objectives nevertheless acquiesce im a decision. ${ }^{118}$ Edelınan has treated rehance on symbolic cues as a commonplace, while Gusfield considers status conflicts a rarity in institutionalized pohitics under the American two-party system. ${ }^{119}$ As Gusfield also makes clear, a symbolic victory in a status conflict does more than assuage fear and resentment: It also affects important status imterests. Any governmental action can be an act of deference because it confers power on one group and limits some other group. ${ }^{120}$ Moreover, the relative status of groups is affected by actions

110. J. GuSFIELD, supra note 109, at 21 .

111. Id. at 175-76.

112. Id. at 177-78, 183-84.

113. Id. at $184-85$.

114. Id. at 186.

115. Id. at $186-87$.

116. Id. at 182 .

117. Id. See generally M. Edelman, The Symbolic Uses of Politics (1964); M. Edelman, Politics as Symbolic Action (1971); M. Edelman, Political Language (1977) (describing how the formal appearance of an equal opportunity to participate in a scemingly rational governmental decisionmaking process induces aequiescence among losing groups who do not obtain desired tangible resources).

118. J. GUSFIELD, supra note 109 , at 182.

119. Id. at $185-86$.

120. Id. at 182. 
that bear on their ways of life. ${ }^{121}$ Legislation that affirms a group's way of life is of particular importance to those attempting to defend or enhance their status. ${ }^{122}$

Gusfield developed this framework as a way of understanding the American Temperance movement's drive to establish Prohibition. According to Gusfield, the Temperance movement originated in the 1820 's as a reaction by the Federalist aristocracy to its loss of political, social, and religious standing. ${ }^{123}$ Although the Federalists' efforts to vindicate a norm of abstinence reflected underlying changes in the status order, advocates of temperance did not attempt to legislate their morality during this period, instead relying solely on inoral suasion. ${ }^{124}$ Although these leaders did not seek a political resolution of the underlying status conflict, they openly asserted that intemperance had dangerous pohtical consequences, including increased risks of "disobedience, renunciation, and rebellion." 125

Later, the Temperance movement was assimilated to a wave of rehgious revivahism during the 1830 's and 1840's. As part of this revivalism, temperance was held up as a inoral virtue, a means of self-improvement that would enable the worker or farmer to establish middle-class respectability. ${ }^{126}$ In contrast to the earher movement in the 1820 's, the push for abstinence was no longer an effort to reform others but was instead an avenue of personal advancement for adherents. ${ }^{127}$ The promotion of temperance was not politicized; rather, it reflected a stable status order with a clear hierarchy of values, which made strategies for achieving upward mobility plain.

During the 1840's and 1850's, however, support for the Temperance movement again shifted. Increasing urbanization and immigration threatened the social, moral, and cultural preeminence of rural Protestant Americans. ${ }^{128}$ Once agam, the drive for Temperance reflected an effort to maintain waning group status. Not surprisingly, the Temperance movement was closely allied with the nativist movement, which reflected similar concerns about urbanization and immigration. During this period, the Temperance movement first sought to resolve these uncertainties about status through legislative intervention. Temperance leaders successfully pursued Prohibition legislation in a number of states,

121. Id. at $182-83$.

122. Id. at 180 .

123. Id. at $37-44$.

124. Id. at 51.

125. Id. at $42-43$.

126. Id. at $44-47$.

127. Id. at $46-47$ (personal development was also affected through participation in fraternal temperance lodges that provided certain economic benefits to inembers).

128. Id. at 55-57. 
although by the early 1890 's, the laws had been largely eliminated. ${ }^{129}$

The declining emphasis on Prohibition legislation after the 1850's and 1860 's paralleled yet another shift in the Temperance movement. In 1872 , the movement adopted a humanitarian orientation that emphasized assimilative reform. ${ }^{130}$ In contrast to the earlier religious revivalists, Temperance leaders of the 1870's considered abstinence not as a means of personal improvement, but as a vehicle for improving the lives of the poor and working classes. ${ }^{131}$ During this period, the movement embraced wide-ranging platforins of social reform. To pursue these broader goals, the Women's Christian Temperance Umion (WCTU) and the national Prohibition party were founded. ${ }^{132}$ According to Gusfield, these efforts reflected a basic satisfaction with the status order. Relatively secure in their social position, Temperance leaders responded to the problems of urban industrialization and immigration with pleas for aniehorative reforms within the system. ${ }^{133}$

By the early 1900's, however, the increasing salience of urban centers and immigrant populations presented a growing challenge to the dominance of rural Protestant Americans. Earher humanitarian reform efforts had failed to deflect this threat. ${ }^{134}$ Once again, the fight to establish Prohibition becanie the proxy for an underlying concern about status. As in the 1850's and 1860's, support for Prohibition was strongest in areas that were Protestant, rural, and nativist; in fact, as the Temperance movement becanie more single-mindedly committed to Prohibition reforms, it grew mcreasingly isolated from progressive reform movements that had shared its earher humanitarian objectives. ${ }^{135}$ A new wave of Prohibition campaigns began, agani culminating in restrictive legislation in a large number of states. ${ }^{136}$ After these state and local victories, the drive for Prohibition took on national dimensions, resulting in the enactment of

129. The Massachusetts Legislature passed the first major Temperance bill in 1838. Called the Fifteen-Gallon law, it prohibited the purchase of hquor in quantities of less than 15 gallons. The bill's primary effect was to restrict drinking among the poor, and it was repealed two years later. Id. at 52-53. The drive to restrict hquor and beer cousumption imtensified during the 1850 's, and by 1856, eight states had passed some form of Prohibition legislation. Id. at 51. Between 1843 and 1893, 15 states passed legislation prohibiting statewide sale of imtoxicants, but by 1906 these laws remamed in force in only three states. Id. at 100 .

130. Gusfield, Social Structure and Moral Reform: A Study of the Woman's Christian Temperance Union, 61 AM. J. Soc. 221 (1955), reprinted in SOClaL Movements AND SoclaL. Change 61-64 (R. Lauer ed. 1976).

131. Id. at $63-68$.

132. The WCTU in particular adopted far-reaching plans for social reform. Id. at 62-64; J. GUSFIELD, supra note 109, at 94.

133. Gusfield, supra note 130 , at 64,67 .

134. Id. at 64-65, 67-68.

135. J. GUSFIELD, supra note 109 , at 100-10.

136. Seven states passed Prohibition laws between 1906 and 1912. By 1919, when Prohibition was elevated to a constitutional mandate, 19 more states had passed restrictive legislation. Id. at 100. 
the eighteenth amendment, which stood as a testament to rural, Protestant American values for over a decade. ${ }^{137}$

The eighteenth amendment's proscriptions agamst trafficking in intoxicating hquors were not stringently enforced; one observer has gone so far as to characterize this lackluster effort as "nullification by nonenforcement."138 Underenforcement did not provoke a inajor outcry among Temperance leaders, who appeared satisfied with constitutional vindication of the norn of abstmence, regardless of whether it was fully observed. ${ }^{139}$ Gusfield argues that this complacency confirms the highly symbolic character of status conflicts. ${ }^{140}$

\section{III}

\section{ANALYZING THE BILINGUAL EdUCATION CONTROVERSY AS A STATUS CONFLICT}

Gusfield's analysis of status conflicts can illuminate the bilingual education controversy if Hispamics have used language as a proxy for their culture, customs, and values. Under these circumstances, governinent support of bilingual-bicultural education and TBE programs represents the deference accorded Hispamics' way of life. ${ }^{141}$ Termination of this support would undermine Hispamics' recently acquired and hardwon status.

To evaluate the merits of this approach, this Part will use status conflict analysis as a framework for explaining bilingual education pohcymaking, litigation, and the developinent of the bilingual education and

137. Id. at 106-07, 118-19.

138. Gusfield, Prohibition: The Impact of Political Utopianism, in CHANGE AND CoNTINUITY IN TWentieth-Century AMERICA: The 1920's 257, $269-70$ (J. Braeman, R. Bremmer \& D. Brody eds. 1968) (quoting C. MERTZ, THE DRY DECADE 120 (1937)). The eighteenth amendment gave Congress and the states concurrent power to enforce its requirements by appropriate legislation. The major federal enforcement effort was the National Prohibition Act, or Volstead Act. The Act imposed responsibility for detection and suppression of violations on the Commissioner of Internal Revenue in the Treasury Department, rather than on the Department of Justice. The Prohibition Bureau was not brought under the Civil Service, and the salaries of Prohibition agents were considerably lower than those of other personnel. Federal and state appropriations were seldoin large enough to establish an effective legal and police organization. Ineffective organization and weak morale were further aggravated by a succession of appointed Prohibition commissioners. Only after Herbert Hoover was elected President in 1928 did the Bureau become regularized by requiring recruits to pass the Civil Service examination and by bringing its activities under the supervision of the Justice Department. Id. at 270-71.

139. J. GUSFIELD, supra note 109, at 120-21.

140. Id. at 122-24; Gusfield, supra note 138, at 286-90.

141. Bilingual-bicultural education programs most clearly vindicate Hispanics' way of life because they place the Spanish language and related cultural values on a par with English and its attendant cultural norms. TBE programs provide a more ambiguous affirmation since children are ultimately returned to English-speaking classrooms. However, some deference is still accorded to distinctive linguistic and cultural heritages. Certainly, TBE programs display a greater sensitivity to these concerus than ESL and structured immersion programs. 
English-only movements. ${ }^{142}$ Applying Gusfield's work in each of these areas will also enrich his original observations.

\section{A. The Policymaking Process Revisited}

In 1968, the wide publicity and emotionally charged rhetoric surrounding passage of the Bilingual Education Act reflected the participants' belief that more was at stake than a modest grant-in-aid program to fund researcli on bilingual education. As the testimony indicated, proponents viewed the Act not only as a vehicle for upward mobility but also as an endorsement of their language, culture, customs, and values. ${ }^{143}$ The Act's syinbolic impact far exceeded its imitially small effect on the allocation of resources to programs for NEP and LEP children. Yet, just as Temperance leaders did not protest the nullification of the eighteenth

142. Neither Gusfield's analysis nor this Essay examines why certain disputes over status become pohticized and others do not. The dispute over bilingual education is clearly politicized, perhaps in part because it centers around a state-provided service, public education. Of course, in choosing to focus on a public service, the participants also may have implicitly decided to politicize the dispute. By contrast, the Temperance movement focused on the consumption of alcohol, a largely private activity that was not inherently politicized. In fact, the dispute over temperance that arose in the 1820 's did not become a political issue until the 1840's. See supra notes 123-29 and accompanying text.

The readiness with which a status conflict becomes politicized may depend on the general tendency to address disputes in the public forum. For example, some commentators have noted the growing trend to address a variety of issues, including those relating to special education, by elaborating substantive rights and developing trial-type procedural protections. Neal \& Kirp, The Allure of Legalization Reconsidered: The Case of Special Education, in ScHool DAYS, RuLE DAYs 343-45 (D. Kirp \& D. Jensen eds. 1986). But cf. Gusfield, The Modernity of Social Movements: Public Roles and Private Parts, im Societal Growth 302-07 (A. Hawley ed. 1979) (arguing that the state will become a less vital arena for social movements and that the civil rights movement may be the last major movement to rely on centralized state power to effect its demands). The push to convert educational problems into legalistic terms may have mcreased the likelihood that the status conflict underlying the bilingual education controversy would become politicized.

A related issue is why Hispanics selected bilingual education to serve as the proxy for their status. This clooice may in part have been dictated by resource mobilization considerations. Hispanics needed an issue that would unite, rather than divide, them along ethnic lines. Their shared language lieritage was a logical clooice. See Padilla, On the Nature of Latino Ethnicity, 65 Soc. ScI. Q. 651, 653, 655, 658-60 (1984); see also Rodriguez, 'Latino'-A Label Too Wide and Too Narrow for Reality, L.A. Times, Jan. 8, 1987, § II, at 5, col. 1. They also needed to ensure that the issue was of sufficient concern to their constituents that they would mobilize to support it. Recent studies suggest that education is of critical importance to Hispanics, among both long-time residents and more recent immigrants. Garcia \& de la Garza, Mobilizing the Mexican Immigrant: The Role of Mexican-American Organizations, 38 W. PoL. Q. 551, 559 (1985) (citing generally low rates of political and community involvement for Mexican immigrants but noting surprisingly high participation in PTA chapters); Romo, The Mexican Origin Population's Differing Perceptions of Their Children's Schooling, 65 Soc. ScI. Q. 635, 637, 648-49 (1984) (noting that all Mexican-origin groups value education, although their expectations of and degree of alicnation from the school system vary with lengtl of residence). In addition to satisfying resource mobilization requirements, bilingual education enabled Hispanics to distinguish their demands from those of black civil rights groups, who had dominated many of the efforts to combat racial discrimination. Rodriguez, supra.

143. See supra notes $23-27$ and accompanying text. 
amendment by nonenforcement, bilingual education advocates refrained from loudly decrying the Act's consistent underfunding.

However, bilingual education advocates could not simply acquiesce in the Act's underenforcement. Unlike Temperance supporters who were defending their status against the threat of growing urban immigrant populations, bilingual education supporters sought to enhance their status despite a longstanding history of exclusion and prejudice. A symbolic victory for the Teinperance movement was probably more resilient in the face of underenforcement because the message conformed to the traditional status order. The affirmation of rural, Protestant American values merely confirmed people's preexisting beliefs about status. By contrast, the vindication of Hisparics' language, culture, and way of life in the Bilingual Education Act was desigued to revise the status order. Because the Act's message challenged most people's assumptions about status, its symbolic impact was extremely fragile in the absence of any significant changes im school district practices. ${ }^{144} \mathrm{~A}$ wholly discretionary grant prograin therefore could not fully vindicate Hisparrics' status: A mandatory entitlement to bilingual education was necessary.

The Act's supporters turned to administrators and the courts to establish an entitlement that would ensure that sclools devoted a greater sliare of their resources to prograins for NEP and LEP children. These efforts succeeded when OCR issued its 1970 memorandum extending title VI's protections to NEP and LEP students, and the Supreme Court endorsed OCR's position im Lau. By proceeding before administrative decisionmakers whose deliberations on title VI's coverage of NEP and LEP children received relatively little attention, proponents avoided the serious consequences of a widely publicized defeat in the political arena. Had these advocates loudly criticized the underfunding of the Bilingual Education Act, their protests might have been iguored, and the symbolic impact of the Act would have been undermined.

The Lau decision had some symbolic consequences when announced and significant effects on the allocation of resources as applied. Its declaration of riglits affirmed the value of according NEP and LEP children a meaningful opportumity to participate in an educational prograin. Because the opmion did not specify a remedy for the exclusion of NEP and LEP children from the curriculum, however, it did

144. In his analysis of the Temperance movement, Gusfield did not distinguish between the strategies of groups seeking to enhance their status and those seeking to defend it. Apparently, rural Protestant Americans organized around the issue of abstinence, but burgeoning urban immigrant populations did not. The liquor industry mounted the primary opposition to Prohibition laws, but its arguments were predicated on economic self-interest, rather than on concern for a particular way of life. See Gusfield, supra note 138, at 303-04. Consequently, Gusfield's examination of the Temperance inovement did not afford him an opportunity to compare status groups based on whether they were inproving or preserving their position. 
not clearly vindicate the language, culture, and way of life of linguistic minorities. In fact, the decision expressly acknowledged that teaching Englislı to NEP and LEP children miglit be an acceptable alternative, regardless of whether they received native-language instruction or information about their cultural heritage. The Lau decision became associated witl a commitment to programs that relied heavily on nativelanguage instruction only because of the later interpretive gloss in the Lau guidelines, which establislied a strong preference for such prograins over structured immersion and ESL programs. ${ }^{145}$ OCR's interpretation not only affected how resources were allocated to programs for NEP and LEP children but also altered the symbolic impact of the Lau decision.

Originally, congressional enactınent of the EEOA was nothing more than a sympatlietic gesture since it merely reiterated the standard under title VI set fortl in Lau and OCR's 1970 ineinorandum. The EEOA's original symbolic impact on the linguistic minority community was probably quite small compared to the effect of the Bilingual Education Act in 1968. After all, the provision relating to NEP and LEP children was added as an amendment from the floor witl little discussion and was embedded in an omnibus civil rights bill. Moreover, most hinguistic minorities preferred to obtam relief under title VI because of the availability of the Lau guidelines, which endorsed bilingual-bicultural education and TBE programs. Ouly later, when title VI's coverage becaine more ambiguous and the Lau guidelines were witlidrawn, did the EEOA begin to have important symbolic and instrumental consequences. Althougl the EEOA lias permitted hitigants to continue to sue successfully for special educational assistance, it less clearly vindicates the language, culture, and values of linginistic minorities since it seenis to permit ESL and structured immersion programs. ${ }^{146}$

As enforcement efforts produced an increasingly important reallocation of resources to bilingual education programs, adversely affected groups organized around both economic interest and status. In 1977-78, when empirical research failed to deinonstrate the effectiveness of bilingual education programs, opponents were able to cliallenge federal support for the programs successfully. The free-for-all surrounding the NPRM in 1980 reffected botl interest-group and status politics. Englisl1speaking teacliers, who were probably concerned about their einployment security in a shrinking job market, mounted a strong attack on the requireinents. At the same time, concerns about official bilingualism and separatism reflected a preoccupation witl the status of English as the preeminent language of tlie United States. ${ }^{147}$

145. See supra notes 33-35 and 38-39 and accompanying text.

146. See supra notes $40-41$ and 53-54 and accompanying text.

147. See supra notes $43-46$ and 50-51 and accompanying text. 
The movement to make Enghish the official language of the Umited States even more clearly derives from a desire to preserve Enghish and the "American" way of life from encroachment by a growing number of linguistic minority groups. The membership is composed of long-time citizens who want to curb immigration that may strain America's resources and undermine its standard of hiving. Other members are immigrants who learned English as a second language and want to ensure that their newfound and perhaps tenuous hold on respectability through assimilation is not undermined. They may beheve that learning Enghish and adopting American values is the only legitimate route to upward social mobility. ${ }^{148}$ Although some supporters are Enghsh-speaking teachers with an economic interest in eliminating bilingual education prograins, these interests have been subordinated to status concerns in the drive to make Enghish the official language. ${ }^{149}$

Only when bilingual education advocates had achieved a significant reallocation of resources did this "status backlash" develop. The symbohc victory associated with the Bilingual Education Act's passage in 1968 did not trigger a strong adverse reaction. The Enghish-only movement mobilized only after funding for bilingual-bicultural education and TBE prograins had greatly increased, and empirical evidence had failed to document the programs' benefits. The mixed research findings made it difficult to justify the programs as purely pedagogical devices designed to promote proficiency in Enghish and achievement in other subjects. The continuing commitment to these programs plainly reflected other objectives, including the vindication of the language, culture, and values of

148. Among voters who favored making English the official language of California, $62 \%$ believed that "everyone hiving here should speak English," and $56 \%$ said that it was "important for immigrants to learn English." Interestingly, among Hispamics who favored the proposal, 68\% endorsed these propositions, a rate nearly $10 \%$ higlier than that among white voters who supported the measure. While $50 \%$ of the general voters who supported the English language amendment contended that it is "important to society to speak the same language," $58 \%$ of Hispanics who voted for the measure agreed with this statement. Apparently, for a substantial segment of the Hispanic electorate, learning English was seen as a key element to participation in American society. Significantly, however, the poll does not indicate whether these voters favored the elimination of bilingual services as a means to achieve an English-speaking society, nor does it report on the degrec to which they wanted to encourage proficiency in Spanish and an awareness of their cultural heritage in addition to acquiring English language skills. California Poll, supra note 61, at 191, 193.

Interestingly, the results among Asian voters who endorsed the measure were soinewhat different. Of these voters, 75\% believed that "everyone living here slould speak English," but ouly about 35\% stated that it is "important for immigrants to learn Englisl1" or "important to society to speak the same language." Apparently, these voters did not attach peculiar significance to the need for immigrants to learn Englisl nor did they believe that fundamental societal needs were at stake. Only further study can illuminate precisely why Asian voters endorsing the measure thought everyone should speak English. Id. at 193.

149. Note, supra note 57, at 520-21 (primary emphasis of English-ouly movement is need for coinmon bond of English to ensure political stability); see supra note 58 and accoinpanying text. 
linguistic minorities, especially Hispanics. ${ }^{150}$ As these political inıplications became clearer, Enghish-only adherents found the programs increasingly threatening to their chosen way of life. They therefore mobilized to promote Englisli-only reforms.

Although the English-only moveinent has succeeded in enacting reforms in a number of cities, counties, and states, it is unclear whether these measures will be effectively enforced. Like Temperance adherents, the Enghish-only movement seeks to preserve its place in the established status order agamst a perceived threat. It has rehied on synibolic victories through popular political processes. Because these victories conform to expectations about status, their immediate impact will not be undermined by a lack of enforcement. Consequently, there is a real possibility that, like the eighteenth amendment, Enghisl1-ouly reforms will also be at least partially nullified by nonenforcenient.

\section{B. The Litigation Process Reexamined}

Both Otero and Zambrano share characteristics consistent with the view that the bilingual education controversy enbodies a status conflict. In each case, the plaintiffs demanded bilingual-bicultural education or TBE programs, while the districts typically favored heavier reliance on ESL instruction. These differences arose despite ongoing legislative, judicial, and administrative efforts to define a school district's obligations to NEP and LEP students. Because ESL is a less expensive instructional program, ${ }^{151}$ the school districts' claims can be partly explained in terms of budgetary constraints. However, the plaintiffs' strong preference for native-language instruction is consistent witl a desire to vindicate their culture, custorns, and values, and the districts' choice of ESL programs may also reflect a tendency to uphold the traditional status order. ${ }^{152}$

Both cases certainly had a strong syinbohic impact on the surrounding cominunity, at least in part because they attracted considerable media attention. In Otero, the plaintiffs n1ay have favorably influenced

150. For example, John Molina, the director of the Office of Bilingual Education, responded to the AIR evaluation by explaining:

You actually can't evaluate a bilingual education program. It is philosophy and management. You can evaluate courses. For example, evaluation should be limited to reading, mathematics, science and social science. I think we need a tremendous amount of research in order to determine what are the best methods and if children learn in languages other than English.

D. RAviTch, supra note 27, at 278. Professor Ravitch termed Molina's answer "a blunt admission that bilingual education proceeded from ideological grounds, and not as a result of research validating the best inethods of teaching children of linited English-speaking ability." Id.

151. Birman \& Ginsburg, Introduction: Addressing the Needs of Language-Minority Chlldren, in Bilingual Education, supra note 3, at xvi-xvii; B. Reyes \& M. Siegel, supra note 79, at 41 .

152. See D. TYACK, THE ONE BEST SYSTEM 104-09 (1974) (when inmigrant groups sought to influence school policies by imposing their values or affirming their subcultures, school personnel typically endorsed traditional values, which they took for granted as self-evident). 
the status accorded their way of life, even though they failed to persuade the court that bilingual-bicultural education should be required. That a politically moderate Chicano businessinan testified for the plaintiffs indicated that their views were gaining wider acceptance in the Chicano community. The local newspaper acknowledged that whatever the decision, the case had deinonstrated the importance of recognizing the special needs of linguistically and culturally different children. ${ }^{153}$

In Zambrano, not ouly did the media generate interest in the dispute, but the BDAC also used the bilingual master plan as a rallying cry to spark widespread community involvement. Supporters appeared by the hundreds at public hearings, and popular outrage at the district's countersuit may ultimately have forced it to the bargaining table. Moreover, continuing public pressure on the school board probably improved the plaintiffs' chances to obtain a favorable agreement. ${ }^{154}$

Although these machinations may appear to be nothing more than another example of interest-group bargaining over educational resources, evidence suggests that more than pedagogy was at stake for the Zambrano plaintiffs. The plaintiffs were initially reluctant to enter into settlement negotiations with the district because they wanted a full trial and complete victory "to teach the [d]istrict a lesson."155 After the agreement was reached, the plaintiffs hailed it as a great triuniph. Now that the consent decree is being implemented, linguistic minority parents, including soine of the named plaintiffs, reinain heavily involved in BDAC meetings. The parents value this involvement because "[i]t marks their right to participate in decisions affecting their children's schooling and confers dignity on their linguistic heritage."156 These parents denonstrate a high degree of ethric and linguistic consciousness at the meetings. ${ }^{157}$

Otero and Zambrano also demonstrate the polarization and heated enotional responses that often accoinpany a status conflict. In each case, the hitigation was highly acrimomious, and even traditional professional courtesies broke down. In Zambrano, the animosity among the parties cultninated in the district's filing of a countersuit alleguig harassment by the plaintiffs and their attorney. ${ }^{158}$ The cases also sparked deeply felt reactions in the cominunity at large. In Otero, these feelings manifested theinselves most virulently in threats of violence. In Zambrano, they were evidenced by the heavy attendance and heated debate at public

153. See supra notes 74-75 and accompanying text.

154. See supra notes $86-87$ and $95-98$ and accompanying text.

155. B. Reyes \& M. Siegel, supra note 79 , at 104.

156. Id. at 137.

157. Id. at 140.

158. See supra notes $72,90-94$ and accompanying text. 
hearings and by the outcry that followed the countersuit. ${ }^{159}$

The plaintiffs' substantial involvement in Otero and Zambrano inay have significantly influenced the symbolic impact of the litigation. Although in both cases the school district portrayed the attorneys as outside "agitators," the lawyers reportedly had responded to the plaintiffs' vigorous request for representation, rather than stirring up the lawsuits. ${ }^{160}$ Moreover, the attorneys worked closely with the named plaintiffs throughout each case. ${ }^{161}$ In Zambrano, the plaintiffs even served as hiaisons to their broader ethnic, linguistic, and cultural comınunities. ${ }^{162}$ Because the plaintiffs played a substantial part in the litigation process, they may have been more likely to conclude that the cases enhanced their commumity's status. After all, sophisticated attorneys had deferred to their values.

By contrast, if chents are co-opted or become passive when confronted with counsel's superior expertise, hitigation niay do little to bolster the community's status. A favorable outcoine is apt to be interpreted as a triuniph of legal acunien, rather than as an act of deference to Hisparics' way of life. ${ }^{163}$ NEP and LEP clients may be especially vulnerable to co-optation, making it more likely that a lawsuit will not vindicate their community's status. Typically, these clients are poor ethnic minorities who speak hittle or no Enghish, lave little formal education, and may have distinctive cultural values. ${ }^{164}$ Confronted with an alien legal process, they are apt to defer to attorneys who are well-educated, financially secure, often white, and soinetimes non-Spanish-speaking. ${ }^{165}$ At least in Otero and Zambrano, counsel apparently overcaine

159. See supra notes $73,86-87,95-97$ and accompanying text.

160. The plaintiff's lead attorney in Otero thought that Grand Junction was a poor site for a test case because other districts had more NEP and LEP children and had engaged in more overt acts of discrimination. Yet he concluded that "his primary obligation was to La Voz, a local client attempting to overcome what it saw as concrete aggrievements, rather than to a more abstract national litigation strategy." M. ReBeLl \& A. BLock, supra note 18, at 282 n.11. In Zambrano, the BDAC parents consulted with several attorneys before finding a public-interest lawyer both willing and able to take their case. B. Reyes \& $M$. Siegel, supra notc 79, at 46-51.

161. M. REBELL \& A. BLOCK, supra note 18, at 171 (describing low plaintiff's attorneys adjusted their strategies and theories to fit the needs and perceptions of their clients); B. Reyes \& $M$. Siegel, supra note 79, at 93-95.

162. B. Reyes \& M. Siegel, supra note 79 , at 101-03.

163. See S. Olson, ClueNTS AND Lawyers 28 (1984). Lawyer domination occurs when: (1) lawyers control the content and management of the case witlout sufficient input from their clients; and (2) clients become so dependent on lawyers that their capacity to function as an organization is impaired in the long run. Id. See generally Denvir, Towards a Political Theory of Public Interest Litigation, 54 N.C.L. REv. 1133, $1144-46$ (1976) (analyzing how litigation affects coinmunity organization).

164. L. Orum, The Education of Hispanics 6-25 (Eric Ed. No. 262-121, 1985).

165. Parents may also be overshadowed by English-speaking representatives of the Hispanic community, such as Chicano educators, who become involved in the case. Cf. Post-Trial Brief of Defendant at 43-47, Keyes v. Scliool Dist. No. 1, 576 F. Snpp. 1503 (D. Colo. 1983) (discussing 
the barriers to meaningful client involvement that such differences in language, culture, ethnicity, education, and social status frequently present.

\section{The Development of the Bilingual Education and English-Only Movements}

In addition to illuminating the policymaking and litigation processes, status conflict analysis is helpful in evaluating the evolution of the bilingual education and Englisl1-only movements. Because the bilingual education moveinent souglit to enhance its status, it was less able to rely on popular political processes that are apt to affirm tlie longstaniling, generally accepted status order. Moreover, the inoveinent had limited resources available with which to overcome this popular inertia. Still, it liad to ensure that any fragile symbolic victories it achieved were bolstered by soine subsequent reallocation of resources to bilingual education. Otlierwise, a purely symbolic impact could be eroded by scliool district practices that continued to conform to the traditional status order.

To stand any cliance of success in the legislature, bilingual education proponents had to ally theinselves with other civil riglits groups. Yet, these alliances typically resulted in omnibus bills that relegated bilingual education to the background. During legislative deliberations, bilingual education was consistently oversliadowed by otlier civil riglits issues, sucl as segregation and busing. Only during dehiberations on the Bilingual Education Act did Congress focus exclusively on the problems of NEP and LEP children. The modest grant-in-aid program that emerged from these discussions arguably deinonstrates the limited potential of this narrow legislative reform effort. ${ }^{166}$

Bilingual education advocates therefore confronted a dilemnia: They could denand specific legislative consideration of their needs and reap extremely limited reforms, or they could join civil riglts coalitions to gam more sweeping reforms that accorded little special attention to their concerns. Neitlier outcome was satisfactory for Hispanics who accorded a umique importance to language as a proxy for their way of life. To achieve a more ineaningful endorseinent of their language, culture, and values, these advocates had to turn to decisionmakers that were

standing, typicality, and commonality requirements of class action brought by an organization of Hispanic educators as well as students and their parents) (on file with author).

166. Bilingual education proponents may have traded their support on other issues for favorable consideration of the Bilingual Education Act, thereby using coalitions to promote a more simgleminded focus on the issue. Because the Act benefited a much narrower class, however, bilingual education supporters probably expended much of their political capital on catapulting the issue to prominence. They were therefore unable to extract more stringent legislation. Again, imterest-group bargaining plays a role in explaiming the legislative process, but status conflict analysis illuminates why proponents were willing to trade off a great dcal to make bilingual education a salient issne. 
not directly accountable through the electoral process: the courts and administrative agencies. Reheved of some of the need to forge broader coalitions, proponents could insist more narrowly on exphicit approval of bilingual-bicultural education and TBE programs as a means of affirming their way of life. ${ }^{167}$ As they achieved judicial and administrative victories, they were able to use them to persuade the legislature that its choices in enacting a bilingual education act or in funding programs were quite limited. ${ }^{168}$ This strategy enabled bilingual education supporters to highlight bilingual education as a smgularly important symbol of their status.

In contrast to bilingual education proponents who have relied heavily on judicial and administrative as well as legislative intervention, English-only reformers have typically relied on legislative action and popular referenda. Because the Enghish-only moveinent seeks to preserve the existing status order, it is better able to capitalize on popular political processes than are bilingual education advocates, who challenge that order. ${ }^{169}$ The high visibility of these processes, especially the popular referendum, makes them particularly useful in symbohically affirming the value of the Enghish-only reformers' way of life.

However, the message sent by these measures is often clouded by the need to generate widespread sympathy for the proposals and the opportunity for broad-ranging participation in the referendum process. In Califorma, for example, one survey found that few voters had any clear idea of what the official language proposal ineant. Soine even simultaneously supported the Enghish-only amendment and bilingual education or bilingual ballots. ${ }^{170}$ The Enghisli-only movement inay therefore achieve highly salient symbohic victories with extremely ambiguous connotations. ${ }^{171}$ In the sliort run, this ambiguity inay not greatly trouble the

167. Although the plaintiffs in Lau did not request a specific remedy, most litigants, like those in Otero and Zambrano, have demanded bilingual-bicultural education or TBE programs. Baker \& de Kanter, supra note 19, at 299-305; Levin, supra note 10, at 37-39. Of course, these demands were significantly shaped by the Lau guidelines, id. at 37, but even after the guidelines' demise, plaintiffs have pressed for such programs under the EEOA. Baker \& DeKanter, supra note 19, at 302-05; Roos, Implementation of the Federal Bilingual Education Mandate: The Keyes Case as a Paradigm, 1 LA RAZA L.J. 257, 265-66 (1986).

168. See, e.g., M. Rebell \& A. BlocK, supra note 18, at 193.

169. See supra notes 101-06 and accompanying text.

170. Trombley, Latino Backing of 'English-Only' a Puzzle, L.A. Times, Oct. 25, 1986, § II, at 6, col. 1.

171. In fact, even some of the popular referenda themselves have been loosely worded. For exainple, in California, the state constitutional amendment provides simply that "English is the official language of the State of California." CAL. ConsT. art. III, § 6(b) (ainended 1986). It goes on to require the legislature to "enforce this section by appropriate legislation" and mandates that the legislature and state officials "take all steps necessary to insure that the role of English as the common language of the State of California is preserved and enhanced." Id. $\S 6($ c) (amended 1986). It further prohibits the legislature from passing any law "which diminishes or ignores the role of English as the common language of the State of California." Id. The ainendment also provides for a 
supporters of English-only reforms. Disagreements about the provision's meaning are likely to become manifest only while implementing it; yet, as previously noted, English-only reformers who seek to affirm the established status order are less pressed to enforce their symbolic triunphs. In fact, they may shy away from enforcement efforts that are apt to disrupt their support by making clear the diverse interpretations of the ineasures. ${ }^{172}$

\section{IV}

\section{Some Predictions and Suggestions About Bilingual EDUCATION AND ENGLISH-ONLY REFORMS BASED ON STATUS CONFLICT ANALYSIS}

This Essay would not be complete without using status conflict analysis to indulge in some speculation about the future of bilingual education policymaking and litigation as well as the prospective development of the bilingual education and English-only movements. These predictions are offered only tentatively, however, in higlt of the myriad factors that can influence these complicated events.

\section{A. The Policymaking Process Projected}

So far, the English-only moveinent lias pursued highly syınbolic affirmations of its values without evincing much concern about subsequent enforcement. The English-only movement is unlikely to address the allocation of educational resources except when bilingual education supporters press for bilingual-bicultural education and TBE programs. ${ }^{173}$ These battles are most likely to occur when legislatures are deliberatimg on bilingual education acts or appropriating funds under them. ${ }^{174}$ The Englisl1-only movemeut's "reactive" posture is wholly consistent witl its effort to defend, rather than alter, its status.

private right of action to enforce its provisions. Id. § 6(d) (amended 1986). The amendment's allencompassing wording is apt to spark a number of competing interpretations. Trombley, supra note 61; L.A. Times, Oct. 3, 1986, § II, at 4, col. 1.

172. For example, efforts to eliminate foreign language advertising have created considerable dissension within the English-only movement. May, Opposition Intensifies to Ads Using Spanish, L.A. Times, Sept. 8, 1986, § I, at 21, col. 1.

173. After the passage of the English-only amendment in California, leading officials were reluctant to enact legislation to implement its requirements. Ingram, Prop. 63 Backers Aim at Bilingual Education, L.A. Times, Nov. 24, 1986, § I, at 3, col. 1. Even an assemblyman who introduced bills to eliminate a wide range of bilingual services after the amendinent's passage expressed doubts as to whether the legislature would endorse his proposals. Trombley, supra note 64; San Francisco Examiner, Nov. 6, 1986, at A.3, col. 1.

174. In California, there is general agreement that English-only advocates will strenuously oppose efforts to extend the state's bilingual edueation provisions, which expire on June 30, 1987. Ingram, supra note 173; Trombley, supra note 64; San Francisco Examiner, supra note 173. 
The English-only movement will probably have far less impact on omnibus civil rights statutes, such as title VI and the EEOA, because they treat language barriers as a proxy for discrimination on the basis of race or ethnicity. This framework makes it more difficult for bilingual education advocates or English-only proponents to elevate language to a position of singular importance. Moreover, these statutes are supported by a coalition of civil rights groups. Because of its single-issue orientation, the Enghish-only movement may be less able to forge the alliances necessary to challenge this coalition.

The Englisl1-only movement is unlikely to file many administrative complaimts and lawsuits to change bilingual education programs, although it would undoubtedly respond to any challenges to the validity of Enghish-only measures. Instead, organizational resources are currently being devoted to political campaigns for Englisl1-only reforms across the country. ${ }^{175}$ These campaigus have produced widely publicized, discrete clianges with a strong symbolic impact. By contrast, administrative actions and litigation tend to be drawn out and may produce only mixed results for English-only supporters, given the strictures of title VI and the EEOA. ${ }^{176}$ Because administrative proceedings are typically less publicized than higher court decisions, they are particularly unattractive avenues of cliange for Enghish-only adherents because of their limited symbolic impact.

Moreover, few members of U.S. English have any direct stake in how Enghisl-only measures are enforced in the schools. Having had little direct contact with bilingual education programs, they are not likely to devote the time and energy necessary to investigate and challenge program implementation; in any event, mere passage of Enghish-only measures vindicates their way of life. ${ }^{177}$ The one exception is Englishspeaking teachers whose jobs may be threatened by bilingual education programs. Again, Enghisli-speaking teachers are apt to assume a "reac-

175. For instance, U.S. English loaned its California chapter $\$ 385,000$ to finance the Englishonly initiative. Trombley, Prop. 63 Finance Infraction Alleged, L.A. Times, Sept. 19, 1986, § I, at 25, col. 1; Nakao, Prop. 63 Opponents Complain About Loan to Plan's Backers, San Francisco Examiner, Sept. 19, 1986, at A6, col. 5.

176. Obviously, districts will remain bound by consent decrees negotiated pursuant to title VI. Baker \& de Kanter, supra note 19, at 307-08. Moreover, the EEOA, which is now the principal source of federal protection for linguistic minority schoolchildren, only requires that districts take "appropriate action" to meet their needs. In the short term, this would clearly seem to allow properly implemented ESL and structured immersion programs. See supra note 54 and accompanying text. However, the prevailing interpretation of the requirement also requires districts to evaluate their programs and modify them if they do not inprove NEP and LEP students' acadeınic achievement. Castaneda v. Pickard, 648 F.2d 989, 1009-10 (5th Cir. 1981). In the longer term, ESL and structured immersion programs might run afoul of the EEOA if ongoing evaluation revealed that they did not adequately enhance NEP and LEP students' opportunity to participate in the educational curriculum.

177. See supra notes $21,58,149$ and accompanying text. 
tive" posture, filing coinplaints only in response to bilingual education advocates' efforts to reallocate resources. Moreover, while displaced teachers inay rely on the Enghish-only ineasure, they are also apt to invoke their vested interests based on seniority. ${ }^{178}$

To the extent that the English-only inovenient interjects itself into bilingual education debates, it will probably rigidify policy discussions by insisting on the unique role of Enghish. Each side will increasingly view language as an absolute value that can not be traded off against other goods. As both sides grow nuore inflexible in their denands for vindication of their language's value, they will insist inore veheinently on specific remedies that validate their ways of life. Each will be even less willing to consider einpirical evidence on the effectiveness of different approaches to teaching NEP and LEP children. Instead, Enghish-only advocates will invariably deinand structured immersion and ESL prograins because they promote the status of Enghish. By the saine token, Hispanics and perhaps other linguistic minority groups will deınand bilingual-bicultural education and TBE prograins that endorse their language, cnlture, and custonis. ${ }^{179}$ It will becoine increasingly difficult to inask this deep-seated conflict through compromises that advance neither side's status objectives.

\section{B. The Litigation Process Predicted}

Bilingual education advocates have rehed heavily on the hitigation process to ensure that programs for NEP and LEP children are adequately funded. However, this process has been increasingly coinphicated by tensions between bilingual education and desegregation and by the proliferation of linguistic minority groups. Bilingual education conflicts with desegregation in two ways. First, implennentation of a desegregation decree often threatens bilingual education progranis that require a minimum nuniber of NEP and LEP students in a particnlar school to trigger prograin requirements. Even where prograins continue after implementation of the decree, they are more likely to rely on ESL because bilingual-bicultural education and TBE prograns are not utihized with a sinall nuinber of students. ${ }^{180}$ Second, to the extent that linguistic minority students nuust be separated froin their Enghish-speaking classmates for special instruction, bilingual education progranis can result in racially or ethnically identifiable classrooins and undesirable

178. See supra note 12 and accompanying text. Of course, to the extent that claims based solely on seniority have proven unsuccessful, English-speaking teachers are apt to rely more heavily on English-only reforms.

179. The polarization of the bilingual education conflict along these lines is already beginning to emerge in California. Ingram, supra note 173; Trombley, supra note 64.

180. Roos, Bilingual Education: The Hispanic Response to Unequal Educational Opportunity, LAW \& CONTEMP. ProBs., Autumn 1978, at 135. 
isolation. $^{181}$

Courts have responded to these tensions in a variety of ways. Some have simply accorded a higher priority to desegregation than bilingual education. Others have allocated NEP and LEP children among the schools covered by a desegregation decree in a way that preserves bilingual education programs. ${ }^{182}$ To avoid classroom segregation, Congress has provided that up to forty percent of the students in a federally funded bilingual education program can be Enghsh-proficient. ${ }^{183}$ The courts and Congress have also required integrated classes in music, art, physical education, and other elective subjects. ${ }^{184}$

The conflict between bilingual education and desegregation diminishes the symbohic impact of lawsuits in vindicating Hispanics' way of life. The hitigation process makes clear the trade-offs required ainong different approaches to combatting racial and ethmic discrimination in the schools. In fact, these trade-offs reflect the omnibus character of the statutes that have spawned the hitigation. By treating language as a proxy for race and ethnicity, these provisions acknowledge that children are vulnerable to various forms of discrimination, which may require distinctive remedies.

What remams uncertain is whether compromises forged in the legislature will endure the hitigation process. When omnibus civil rights bills are passed in Congress, the trade-offs are abstract and remote, but in a lawsuit, they become concrete and immediate. Moreover, litigants are often more deeply committed to specific reinedies than are lobbyists who regularly einploy a wide range of tools to achieve an organizational objective.

Pubhic-interest attorneys who higate a number of bilingual education or desegregation cases can help to prevent the factionatization of plaimtiffs along these lines by placing the plaintiffs' efforts in a broader perspective. Without divestimg clients of ultimate decisionmaking authority, these attorneys can inform them about the wide range of approaches that have been used to fight racial and ethnic discrimination and the continumg commitment to each. If attorneys can persuade plamtiffs seeking desegregation and those seeking bilingual education

181. 1977 House Hearings, supra note 44, at 355-37 (remarks of Professor Gary Orfield, Political Science Department, University of Illinois at Urbana).

182. Roos, supra note 180 , at $135-37$ (describing approaches adopted in cases involving desegregation and bilingual education).

183. Bilingual Education Act, 20 U.S.C.A. \$ 3223(a)(4)(B) (Supp. 1986).

184. E.g., Cintron v. Brentwood Union Free School Dist., 455 F. Supp 57, 63 \& n.9, 64 (E.D.N.Y 1978); see also OFFICE FOR CIVIL RIGHTS, supra note 3, \$§ IV, VI, reprinted in Bilingual Education, supra note 3, at 218-20 (no longer enforced); Bilingual Education Act, 20 U.S.C.A. \$ 3223(a)(4)(C) (requiring participation of NEP and LEP children in regular classes in elective courses, such as art, inusic, and physical education). 
that cooperation is mutually beneficial, then the in-fighting that can potentially stymie ineaningful judicial intervention may be prevented. ${ }^{185}$ To soine extent, the attorneys' success in preserving these alliances will depend on the degree to which the Enghish-only inoveinent rigidifies the focus on language as a basis for vindicating Hispanics' way of life. The more vigorously bilingual education advocates insist on the symbohic affirmation of their language, culture, and customs, the more likely that legislative trade-offs will not survive the hitigation process.

The increasing number of linguistic minority groups also coinphcates the hitigation process in bilingual education cases. Hispanic planitiffs have played a leading role in inany bilingual education cases, even where a number of other linguistic minority groups were potentially affected by the decree. ${ }^{186}$ These other groups have seldom participated actively in formulating hitigation strategies. Courts have frequently iguored their lack of involvement by assuming an identity of interest ainong language groups during the hability phase of a bilingual education case. Judges have, however, suggested that broader participation by these groups is required once liability is established and a reinedy is being formulated. ${ }^{187}$ Such protection at the reinedial phase is probably inore illusory than real. Once a school district lias been found hable, it typically negotiates with the planitiffs to draft a consent agreeinent subject to judicial approval. It is unclear whether previously uninvolved language groups ineaningfully participate in this negotiation process. ${ }^{188}$

If judges inandate inore active participation by a wide range of affected linguistic minorities, Hispanic plaintiffs will liave to forge new alliances with these groups to ensure successful hitigation of their claims. If these coalitions fail to materialize, the lawsuit's potential to vindicate Hisparrics' way of life will be seriously diminished. Not only will the suit's symbolic impact be diluted if groups bicker over the desired rehef, but the case also will probably fail to produce any significant reallocation

185. This problem can be analyzed as a permutation of the Prisoners' Dilemma game, where both parties are better off in the long term by cooperating but believe that they can advance their short-term interests by competing. Because both respond competitively, each suffers both short-term and long-term disadvantages. Perhaps this feature of bilingual education litigation could appropriately be labeled Plaintiffs' Dilemma. See Elliott, Ackerman \& Millian, Toward a Theory of Statutory Evolution: The Federalization of Environmental Law, 1 J.L. EcON. \& ORG. 313, 324-26 (1985).

186. See, e.g., Moran, Foreword-The Lessons of Keyes: How Do You Translate "The American Dream'?, 1 LA RAZA L.J. 195, 201-02 (1986) (Spanish-speaking intervenors and their counsel directed bilingual education case with little or no input from other potentially affected language groups).

187. See, e.g., Keyes v. School Dist. No. 1, 576 F. Supp. 1503, 1506-08 (D. Colo. 1983) (although Hispanic plaintiff-intervenors were found to represent adequately the interests of Indochinese children during the hability phase of the trial, the court reserved authority to order separate representation during the remedy phase).

188. See Moran, supra note 186, at 202. 
of resources. Eventually, litigation will cease to be an effective tool except in jurisdictions characterized by a relatively homogeneous linguistic minority population.

Even if alliances are forged, the very process of coalition building will alter the dynamics of the hitigation process. In contrast to the tensions between desegregation and bilingual education, the tensions among linguistic minorities have not been extensively addressed during legislative deliberations. Congress paid scant attention to bilingual education issues during discussions of title VI and the EEOA, and Hispamics have overshadowed other groups at hearings on the Bilingual Education Act. ${ }^{189}$ Moreover, the tensions between bilingual education and desegregation have proinoted inultiple-issue pohtics by highlighting the fact that the plaintiffs have suffered discrimination not only on the basis of language but also on the basis of race or ethnicity. In building coalitions anong linguistic minorities, however, it will be necessary to emphasize the common denominator of language. By promoting single-issue politics, the formation of these alliances may intensify the commitment to language as a proxy for linguistic minorities' ways of hife and rigidify demands for governmental imtervention to vindicate these values. Under these circumstances, language will develop broader, more diffuse connotations for the participants and will provoke deeper emotional responses.

\section{The Development of the Bilingual Education and English-Only Movements Divined}

As previously noted, because bilingual education proponents sought to alter the status order by enhancing the deference accorded to their way of life, they had to engage in multiple-issue politics, joining with other civil rights groups to promote the reallocation of resources to bilimgual education programs. Because Enghish-ouly advocates are defending their place in the traditional status order, they have been able to pursue single-issue pohitics without an immediate concern about underenforcement of their reform ineasures. ${ }^{190}$

189. See supra notes 101-06 and accompanying text. Several commentators have noted that the Bilingual Education Act primarily responded to Hispanic demands. See, e.g., C. HARRINGTON, supra note 24, at 2; A. LElBowitz, supra, at 9; S. SCHNEIDER, REVOLUTION, REACTION, OR REFORM: THE 1974 BILINGUal EdUCATION ACT 6-7 (1976). In fact, the bilingual education bill as originally introduced in the Senate covered only Spanish-speaking students but was later broadened to cover other linguistic minority groups, presumably to avoid legal challenges and an appearance of inequity. A. LEIBOwITZ, supra, at 15-17; S. SCHNEIDER, supra, at 22, 24. At the 1967 Senate hearings, over 60 people with a Spanish surname testified, while no Asian-surnamed persons appeared. 1967 Senate Hearings, supra note 25, at iii-vi. In recent years, however, other linguistic ininority groups have played a greater role in the developınent of bilingual education legislation. $L$. Orum, The Bilingual Education Act of 1984: Community Involvement in Policy DEVELOPMENT 6 (1984).

190. For a description of another group that has engaged in single-issue politics, see Kristin 
The prevalence of coalition-building and multiple-issue politics may have significant implications for eacli group's long-term resiliency. The bilingual education movement, by participating in coalitions and concerning itself with a number of civil rights issues, has diversified its political portfolio in a way that inay improve its chances for survival. That is, if advocates encounter defeat in pursumg a particular reform, they can redirect their energies to other issues that promise greater opportumities for success. Conversely, if they succeed im one reform effort, supporters will not disband as readily as would a single-issue group because other reforms will remain on the agenda. ${ }^{191}$ Of course, if the Englisli-only movement's empliasis on language forces bilingual education advocates to adopt a more single-minded commitment to this issue, their organizational resiliency may be impaired.

The Englisli-only movement's exclusive focus on promotimg the English language could jeopardize its cliances for long-term survival. If a single-issue political group consistently fails to achieve desired reforms, it is more likely to lose members who become pessimistic about the possibilities for cliange and caimot devote themselves to alternative organizational objectives. For exanıple, the WCTU's membership declined markedly after the repeal of Prohibition. Faced with a clianged social and political environment that was more hostile to a norm of total abstinence, the WCTU nevertheless retained its smgle-minded commitinent to temperance. As a consequence, its support, especially aniong the imiddle and upper imiddle classes, steadily diminislied. The WCTU's former adlierents could no longer identify witl the largely discredited and unattainable goal of mandatory abstinence. ${ }^{192}$ On the otler liand, if a singleissue group succeeds in promoting desired reforms, its membership is more likely to become apathetic and quiescent. For example, the

Luker's analysis of the anti-abortion movement. K. LUKER, supra note 108, at 223-24. Interestingly, until recently, adherents of the "right to choose" have been less likely to be single-issue voters. Id. at 286 n.11.

191. For a general description of the life cycle of social movennents, including a discussion of their organizational decline, see C. STEwaRT, C. SMith \& R. DENTon, Persuasion and Social MOVEMENTS 37-50 (1984). Of course, economies of scale may also lead groups to diversify when start-up costs are prohibitive. Elliott, Ackerman \& Millian, supra note 185, at 323. Multi-purpose organizations may confer other advantages as well. For example, groups that deal with multiple issues may better understand how various problems relate to one another and inay more accurately predict the diverse ramifications of reform.

192. Gusfield, supra note 130, at 62-63, 72-75. Current WCTU members express moral indignation at the defection of middle and upper middle class inembers. Id. at 70-73. This new emphasis on moral outrage may signal a shift im the WCTU's relevant audience. Political appeals to establish Prohibition were undoubtedly directed at both meinbers and nonmembers, while angry moralizing about the defection of former adherents is probably aimed at the remaining membership. Rather than shaming middle and upper middle class defectors into rejoining, these denunciations are designed to retain the current membership by pronoting in-group sohdarity. This change in focus may represent an implicit acknowledgment that the WCTU's temperance objective no longer can coinmand broad politieal appeal. 
WCTU's broad-ranging commitment to humanitarian reforms in the 1870's may have been designed to stave off apathy among members after the successful pursuit of Prohibition legislation in the 1840's through the 1860 's. ${ }^{193}$ So far, the English-only movement has successfully pursued reforms at the state and local level. Whether it will become apathetic after these initial successes or will broaden its reform agenda to maintain an active membership remains an open question. ${ }^{194}$

\section{CONCLUSION}

Analyzing the bilingual education and English-only movements as part of a status conflict provides a useful supplement to interest-group bargaining analysis. Status conflict analysis is especially helpful in understanding why ongoing government intervention and empirical research have done relatively little to temper the highly emotional quality of the debate. Much more is at stake for the participants than optimizing the allocation of educational resources based on current pedagogical theories. For each side, language has become a proxy for their culture, customs, and values. If, for the foreseeable future, the United States will remain what Theodore Roosevelt termed a polyglot boarding house, the clash over bilingual education and English-only reforms will continue to reflect the status we accord its dwellers.

193. See supra notes $130-33$ and accompanying text. Of course, this does not explain why the WCTU was able to diversify its goals in the 1870's after the successful pursuit of Prohibition legislation, but was not able to do so in the 1930's after the repeal of Prohibition. Perhaps, the WCTU was able to consider supplemental objectives so long as temperance remained a central organizing principle. Once abstinence became a discredited norm, however, the WCTU could not turn to other goals as substitutes for its self-proclaimed primary goal.

194. Regulating immigration would be a likely topic for a broadened reform agenda as several leaders of the English-only movement have expressed concern about this issue. Trombley, supra note 21 (both the chairman and executive director of U.S. English were active in an organization that lobbied for more stringent immigration laws and lower immigration quotas). 